Board of Governors of the Federal Reserve System

International Finance Discussion Papers

Number 911

December 2007

\title{
Precautionary Demand for Foreign Assets in Sudden Stop Economies: An Assessment of the New Mercantilism
}

\author{
Ceyhun Bora Durdu \\ Enrique G. Mendoza \\ Marco E. Terrones
}

NOTE: International Finance Discussion Papers are preliminary materials circulated to stimulate discussion and critical comment. References in publications to International Finance Discussion Papers (other than an acknowledgment that the writer has had access to unpublished material) should be cleared with the author or authors. Recent IFDPs are available on the Web at www.federalreserve.gov/pubs/ifdp/. This paper can be downloaded without charge from Social Science Research Network electronic library at http://www.ssrn.com/. 


\title{
Precautionary Demand for Foreign Assets in Sudden Stop Economies: An Assessment of the New Mercantilism
}

\author{
Ceyhun Bora Durdu \\ Federal Reserve Board \\ Enrique G. Mendoza \\ University of Maryland and NBER \\ Marco E. Terrones \\ International Monetary Fund
}

\begin{abstract}
Financial globalization had a rocky start in emerging economies hit by Sudden Stops. Foreign reserves have grown very rapidly since then, as if those countries were practicing a New Mercantilism that views foreign reserves as a war-chest for defense against Sudden Stops. This paper conducts a quantitative assessment of this argument using a stochastic intertemporal equilibrium framework in which precautionary foreign asset demand is driven by output variability, financial globalization, and Sudden Stop risk. In this framework, credit constraints produce endogenous Sudden Stops. We find that financial globalization and Sudden Stop risk can explain the surge in reserves but output variability cannot. These results hold using the intertemporal preferences of the Bewley-Aiyagari-Hugget precautionary savings model or the Uzawa-Epstein setup with endogenous impatience.
\end{abstract}

Keywords: Fisherian Deflation, Liability Dollarization, Financial Globalization, Credit Constraints, Precautionary Saving, New Mercantilism, Sudden Stops

JEL Codes: F41, F32, E44, D52

* Author notes: This paper was prepared for the Conference on New Perspectives on Financial Globalization held at the IMF, April 26-27, 2007. We thank the discussant, Dave Backus, for his thoughtful comments, Philip Lane and Gian Maria Milesi-Ferretti for sharing their data on cross-country foreign assets with us, and Laura Alfaro, Ariel Burstein, Woon Gyu Choi, Stijn Claessens, Olivier Jeanne, Jaewoo Lee, Marcus Miller, Romain Ranciere, and Vincenzo Quadrini for their comments. We also acknowledge comments by seminar participants at the Bank of Canada, the Congressional Budget Office, IADB, the Latin American Reserves Fund, New York University, the Fall 2007 IFM Program Meeting of the NBER, and the SCE meetings in Montreal. All errors are our own. The views in this paper are solely the responsibility of the authors and should not be interpreted as reflecting the views of the Board of Governors of the Federal Reserve System or of any other person associated with the Federal Reserve System or the International Monetary Fund. 


\section{Introduction}

The early stages of financial globalization in emerging economies were characterized by a series of financial and economic crises known as Sudden Stops. The indexes of capital account liberalization constructed by Edwards (2005) and Chinn and Ito (2005) show that financial globalization progressed significantly in these economies since the late 1980s (see Figure 1). The waves of Sudden Stops that followed began with the Mexican crisis of 199495. Table 1 lists 18 Sudden Stop episodes that occurred between 1994 and 2002. Following these crises, emerging economies accumulated record-high stocks of foreign reserves. Table 1 shows that the median increase in reserves was 7.7 percent of GDP (measured as the crosscountry median of the differences between each country's average reserves-to-GDP ratio from the year of the country's Sudden Stop to 2004 and the average from 1985 to the year of the Sudden Stop). ${ }^{1}$ The increase was particularly sharp in the Asian Sudden Stop countries, where the median increase in reserves exceeded 13 percent of GDP! ${ }^{2}$

A popular view in policy institutions and academic circles is that this surge in reserves represents a form of self-insurance that countries have taken against future Sudden Stops: Having realized that the sudden loss of access to capital markets is a shortcoming of financial globalization, and being aware of the limited financial mechanisms available to cope with Sudden Stops, emerging economies opted for a New Mercantilism in which large holdings of reserves are viewed as a war chest for defense against Sudden Stops. Aizenman and Lee (2007), Alfaro and Kanczuk (2006), Caballero and Panageas (2006), Choi, Sharma, and Stromqvist (2007), Jeanne and Ranciere (2006), and Jeanne (2007) examine key features of this New Mercantilism, and the potential to develop better insurance mechanisms.

This paper conducts a quantitative assessment of the New Mercantilism. We use a dynamic stochastic general equilibrium framework of optimal precautionary demand for foreign assets in a small open economy with incomplete asset markets. We quantify the effects of three key factors that drive precautionary savings in this framework: (1) changes in the business cycle variability of output, (2) financial globalization (i.e., the removal of barriers affecting international asset trading), and (3) self-insurance against Sudden Stops.

The analysis proceeds in two stages. The first stage uses a canonical one-sector model of an endowment economy that faces noninsurable shocks in domestic income. Those shocks are noninsurable because asset markets are incomplete, but the economy still has access to a frictionless credit market in which it can borrow or lend at the world's risk-free interest rate. The model is calibrated to match the variability and persistence of output in Sudden Stop

${ }^{1}$ In most Sudden Stop countries, the change in reserves has been larger than the change in net foreign assets indicating large portfolio shifts that are beyond the scope of this paper. Our focus is on how much of the increase in assets can be explained by precautionary motives. Still, portfolio considerations can be important for studying the surge in reserves (Alfaro and Kanczuk, 2006; Jeanne 2007) and the dynamics of Sudden Stops (Durdu and Mendoza, 2006).

${ }^{2}$ Setting the breakpoint in the Sudden Stop year is not critical. A widespread surge in reserves is also evident when comparing average reserves across the 1986-2004 and 1970-1985 periods. Given that 1985 is often viewed as the starting year of the globalization process, we can also say that reserves surged along with financial globalization. 
economies and then used to compute the optimal short- and long-run dynamics of foreign assets triggered by changes in output variability and financial globalization.

The second stage of the analysis studies a two-sector production economy with endogenous Sudden Stops. The economy has a tradable-goods sector and a non-tradable goods sector, and nontradables are produced with imported intermediate goods (which are priced in world markets). This economy features "liability dollarization" because non-statecontingent debt is denominated in units of tradables. Here, we reexamine the adjustments in foreign assets driven by financial globalization and business cycle volatility. The main goal, however, is to quantify the increase in foreign assets due to optimal self-insurance against Sudden Stops. To that end, we introduce Mendoza's (2002) collateral constraint that limits debt not to exceed a fraction of the value of total income in units of tradables. This constraint causes endogenous Sudden Stops because, when it binds, the output and price of nontradables collapse, tightening the credit constraint further and setting in motion Fisher's (1933) classic debt-deflation mechanism. In this setup, precautionary saving takes into account how foreign asset holdings alter the probability and the magnitude of Sudden Stops.

Our quantitative analysis yields three key findings: (1) Financial globalization, even without Sudden Stops, can produce large increases in mean foreign asset holdings; (2) the risk of Sudden Stops also produces large increases in foreign assets, even when the long-run variability of output is unaffected by Sudden Stops; (3) changes in output variability cannot explain the surge in reserves. The models predict increases in foreign assets in response to higher income variability. In the data, however, there is no evidence of systematic increases in the standard deviation of cyclical output for Sudden Stop economies in the era of financial globalization (see Table 2 and Figure 2). In some countries it increased, but in many others it fell, and the mean and median ratios of pre- v. post-globalization output variability exceed 1. Looking at sectoral GDP variability, nontradables GDP shows the same pattern as aggregate GDP, and the variability of tradables GDP rose (see Table 2), but not by the magnitudes that the model would require to explain the surge in reserves.

Our model also yields an important result in terms of the dynamics associated with the surge in reserves: The large buildup of foreign assets in response to financial globalization or Sudden Stop risk is a slow, gradual process characterized by current account surpluses and undervalued real exchange rates. Those dynamics do not require central bank intervention to target the real exchange rate in efforts to promote exports. Hence, our results can resolve the dichotomy dividing self-insurance-based explanations of the surge in reserves (Aizenman and Lee, 2007) from explanations based on an alternative interpretation of the New Mecantilism arguing that countries desire to maintain external surpluses and undervalued exchange rates (Dooley, Folkerts-Landau and Garber, 2003).

We study precautionary savings under two specifications of preferences that have not been compared before: the Bewley-Aiyagari-Hugget (BAH) approach (which for a small open economy requires a constant, exogenous rate of time preference higher than the world interest rate) and the Uzawa-Epstein (UE) approach (which features an endogenous rate of time preference). The BAH approach is widely used in the precautionary savings literature, whereas the UE approach is often used in Real Business Cycle (RBC) models of small open economies with incomplete markets. Both approaches feature precautionary savings because agents build a buffer stock of savings to enhance consumption smoothing. However, the 
elasticity of mean foreign assets with respect to the interest rate differs sharply in the two approaches, and therefore, their quantitative implications for precautionary savings differ. In particular, we found that the BAH setup predicts larger stocks of precautionary savings and a higher interest elasticity of mean asset holdings than the UE setup.

The BAH approach requires a constant rate of time preference higher than the interest rate because, if the two are equal, optimal precautionary savings would imply accumulating an infinite amount of foreign assets: Agents desire nonstochastic consumption, but they need an infinitely large buffer stock of assets to support it because income is stochastic and capital markets do not offer enough insurance instruments to diversify country-specific income risk fully. Mean foreign assets under this approach increase as the gap between the interest rate and the rate of time preference narrows, with mean foreign assets (and their elasticity) going to infinity as the rate of interest converges to the rate of time preference from below. Thus, at interest rates close to the rate of time preference, the BAH setup predicts that small variations in the interest rate cause large changes in mean foreign assets.

The UE approach models the rate of time preference as an increasing function of past consumption but imposes conditions that limit the magnitude of this "impatience effect." The UE approach yields a long-run rate of time preference that converges to the world interest rate in a nondegenerate equilibrium and a well-behaved stochastic stationary state in which mean asset holdings are less sensitive to changes in the world real interest rate. In fact, in our quantitative experiments, the elasticity of mean foreign assets in the UE setup is approximately constant at high or low interest rates.

A contribution of our analysis is that the effects of business cycle volatility, financial globalization, and Sudden Stop risk on foreign assets are examined within a common framework and under alternative preference specifications. The aim to explore the implications of these three determinants of precautionary savings was motivated by the promising results obtained in the existing literature that has examined the role of each factor separately (see Fogli and Perri (2006), Mendoza, Quadrini, and Rios-Rull (2007) Mendoza (2002), and Durdu (2007)).

The rest of the paper is organized as follows. Section 2 presents the one-sector model and examines its quantitative implications. Section 3 presents the two-sector model with liability dollarization and endogenous Sudden Stops. Section 4 presents our conclusions.

\section{One-Sector Endowment Economy}

\subsection{Structure of the Model}

Consider a small open economy inhabited by a representative agent that consumes a composite good $c$. The agent's preferences are given by

$$
\begin{aligned}
& E_{0}\left[\sum_{t=0}^{\infty}\left\{\exp \left(-\sum_{\tau=0}^{t-1} v\left(c_{\tau}\right)\right)\right\} \frac{c_{t}^{1-\gamma}}{1-\gamma}\right], \\
& v(c)=\rho^{U E} \ln (1+c) \text { or } \ln \left(1+\rho^{B A H}\right)
\end{aligned}
$$


Period utility has the form of constant relative risk aversion (CRRA), and $\gamma$ is the relative risk aversion coefficient. The time preference function $v(c)$ takes one of two forms. With the UE formulation, the rate of time preference is endogenous and given by $v(c)=\rho^{U E} \ln (1+c)$, where $\rho^{U E}>0$ measures the elasticity of the rate of time preference with respect to $1+c$. With the BAH formulation, the rate of time preference is given by the standard constant fraction $0<\rho^{B A H}<1$ (i.e., the typical exogenous discount factor is $\beta \equiv 1 /\left(1+\rho^{B A H}\right)$ ).

The economy chooses consumption and foreign assets as to maximize (1) subject to the standard resource constraint:

$$
c_{t}=\varepsilon_{t} y-b_{t+1}+b_{t}(1+r)+A
$$

The economy's mean or trend income, $y$, is subject to random shocks, $\varepsilon_{\mathrm{t}}$, which follow a first-order, irreducible Markov chain. Foreign assets, $b$, are one-period bonds traded in a frictionless global credit market. These bonds pay a net risk-free real interest rate equal to $r$ (so the gross interest rate is $R \equiv 1+r$ ). Given that in the data absorption includes investment and government expenditures, and not just private consumption, we introduce a constant lump-sum level of exogenous absorption $A$ that will allow us to calibrate the model to match output shares of $c$ and $b$ consistent with actual data.

\subsection{Equilibrium}

The optimization problem of this small open economy is analogous to the optimization problem of a single individual in the heterogenous-agents models of precautionary savings (e.g., Aiyagari, 1994; or Hugget, 1993). As in those models, CRRA utility implies that the marginal utility of consumption goes to infinity as consumption goes to zero from above, making the economy "extremely averse" to consumption and savings plans that would leave it exposed to the risk of "very low" consumption at any date and state of nature. To rule out these plans, agents in this economy impose on themselves Aiyagari's Natural Debt Limit, by which they never borrow more than the annuity value of the worst realization of income: $b_{t+1} \geq-\min \left(\varepsilon_{t} y+A\right) / r$. In addition, following Aiyagari (1994), we can impose an ad-hoc debt limit $\phi$ such that $b_{t+1} \geq \phi \geq-\min \left(\varepsilon_{t} y+A\right) / r$.

If $\phi$ does not bind, the optimality condition of the economy's maximization problem is

$$
U_{c}(t)=\exp \left(-v\left(c_{t}\right)\right) E_{t}\left[U_{c}(t+1)\right][1+r]
$$

$U_{c}(t)$ denotes the lifetime marginal utility of date- $t$ consumption. In the BAH setup, $U_{c}(t)$ is just the standard period marginal utility of $c_{t}$. In the UE setup, however, $U_{c}(t)$ includes both the period marginal utility of $c_{t}$ and the impatience effects by which changes in $c_{t}$ affect the subjective discounting of all future utility flows after date $t$.

A competitive equilibrium for this economy is defined by stochastic sequences $\left[c_{t}, b_{t+1}\right]_{t=0}^{\infty}$ that satisfy the Euler equation (3) and the resource constraint (2) for all $t$. The structure of asset markets has important implications for this equilibrium. If the economy has access to complete insurance markets to fully diversify away all the risk of domestic income fluctuations, the equilibrium would feature a constant consumption stream and the economy's wealth position vis-à-vis the rest of the world would be time and state invariant. 
If the asset market is limited to non-state-contingent bonds, however, the wealth position changes over time and across states of nature, and consumption cannot attain a perfectly smooth path. With BAH preferences, the economy attains a well-defined long-run distribution of foreign assets only if $\beta[1+r]<1 .{ }^{3}$ With UE preferences, a well-defined longrun distribution of assets exists if $\rho^{U E} \leq \gamma$ (see Epstein, 1983). ${ }^{4}$

The competitive equilibrium can be characterized in recursive form in terms of a decision rule for bonds at date $\mathrm{t}+1, b^{\prime}(b, \varepsilon)$, as a deterministic function of date- $t$ assets $b$ and the date- $t$ realization of income $\varepsilon$, that solves the following Bellman equation:

$$
\begin{aligned}
& V(b, \varepsilon)=\max _{b^{\prime}}\left\{\frac{c^{1-\gamma}}{1-\gamma}+\exp (-v(c)) E\left[V\left(b^{\prime}, \varepsilon^{\prime}\right)\right]\right\} \\
& \text { subject to } \quad c=\varepsilon y-b^{\prime}+b R+A
\end{aligned}
$$

In the quantitative analysis, we solve this Bellman equation using value function iteration methods (see Durdu, Mendoza and Terrones (2007) for details). We use Tauchen and Hussey's (1991) quadrature algorithm (THQA) to transform time-series processes of income derived from actual data into a Markov process of $\varepsilon$ for model simulations.

\subsection{Calibration}

The baseline calibration of the model is designed so that the deterministic stationary equilibrium using UE preferences matches a set of statistics from the Mexican economy, including the ratio of net foreign assets to GDP. The calibration to Mexico is not critical for our key findings. As we discuss later, the results of sensitivity analysis show that our findings are robust to changes in parameters and in the variability and persistence of output in the range of those observed in the countries listed in Table 1.

The BAH setup does not have a well-defined deterministic stationary equilibrium, because without uncertainty, $\beta R<1$ implies that consumption falls at a gross rate of $(\beta R)^{1 / \gamma}$ until the economy hits the debt limit $\phi$. Hence, to complete the calibration of the $\mathrm{BAH}$ setup we keep all the parameters as in the UE setup and set $\phi$ and $\beta$ to values such that the model with BAH preferences matches the long-run average of foreign assets and the cyclical standard deviation of consumption in the data.

Table 3 shows the baseline calibration parameters. The CRRA coefficient is set to the standard value $\gamma=2$. Mean income is normalized to $y=1$ so that steady-state allocations can be interpreted as ratios relative to average GDP. We set $b=-.44$, which is the average of Mexico's net foreign assets-GDP ratio over the 1985-2004 period in the database constructed by Lane and Milesi-Ferretti (2006). The consumption-GDP ratio is set to 69.2

3 In this case, the long-run averages of assets and consumption are finite. In contrast, with $\beta(1+r) \geq 1$, assets diverge to infinity in the long run because marginal utility converges to zero almost surely (see Ch. 17 in Ljungqvist and Sargent, 2004).

${ }^{4}$ Foreign assets converge to a well-defined long-run distribution because the rate of time preference increases (decreases) relative to the interest rate if consumption and assets rise (fall) "too much" in the long run, and this changes incentives for savings in favor of reducing (increasing) asset holdings. 
percent $(c=0.692)$, in line with the average consumption-output ratio in Mexican data. The real interest rate is set to 5.9 percent $(R=1.059)$, which is the average of Uribe and Yue's (2006) real interest rate including the EMBI spread for Mexico. The model abstracts from default risk, but because the real interest rate is constant, it seems more reasonable to set it at a constant representative of the interest rate of Mexico's foreign debt than to set it equal to the interest rate on U.S. T-Bills. ${ }^{5}$ Given the values of $y, c, b$ and $R$, the resource constraint implies that $A=y+b(R-1)-c=0.282$.

In the UE setup, the value of the time preference elasticity follows from the steady-state condition that sets the rate of time preference equal to $R: \rho^{U E}=\ln (R) / \ln (1+c)=0.109$. This implies a subjective discount factor of $(1+c)^{-0.109}=0.944$. In the $\mathrm{BAH}$ setup, we match Mexico's average net foreign assets of -44 percent and the standard deviation of consumption over the business cycle (3.28 percent) by setting $\phi=-0.51$ and $\beta=0.94$, which implies $\rho^{B A H}=0.064$. Notice that in theory, for any given $\phi<-0.44$, there is a value of $\beta$ high enough so that the model with BAH preferences yields an average of assets of -44 percent. However, we found that for $\phi<-1$, the values of $\beta$ that can yield this mean of assets result in stochastic steady states that assign non-trivial probabilities to unrealistically high debt ratios, and the variability of consumption exceeds the actual measure by large margins. Conversely, with tight ad-hoc debt limits of 50 percent of GDP or less, the long-run distribution of assets predicts that the economy spends most of the time at the debt limit (i.e., the long-run probability of observing $b=\phi$ is "too high").

The Markov process of income shocks is set to match the standard deviation and firstorder autocorrelation of the Hodrick-Prescott-filtered cyclical component of GDP in annual Mexican data for the 1965-2005 period. Cyclical GDP follows a stationary AR(1) process, $y_{t}=\rho_{y} y_{t-1}+e_{t}$, with $\sigma_{y}=3.3$ percent, $\rho_{y}=0.597$ and $\sigma_{e}=\sqrt{\sigma_{y}^{2}\left(1-\rho_{y}^{2}\right)}=2.65$ percent. Using 5 nodes in the vector of realizations, THQA produces a Markov process for $\varepsilon$ with 3.29 percent standard deviation in output, 0.550 autocorrelation and 2.64 percent standard deviation in output innovations. Hence, this Markov process mimics well actual GDP.

Before reviewing the quantitative findings, we explain how precautionary savings are measured. Precautionary savings are defined as the savings that agents accumulate due to the presence of noninsurable risk, and thus they are usually measured as the difference between the long-run average of assets predicted by a stochastic model and what the same model would predict in a steady state without uncertainty. In the BAH setup, this is the excess of the average assets in the stochastic steady state relative to the debt limit $\phi$, because without uncertainty assets always converge to $\phi$. In contrast, precautionary savings in the UE setup is the excess of the long-run average of assets relative to a well-defined deterministic steady state obtained from the condition $\rho^{U E} \ln (1+y+b(R-1))=\ln (R)$. Hence, the standard measure of precautionary savings is hard to compare across the BAH and UE setups, since they do not attain the same deterministic steady state. Because of this limitation, we also study changes in precautionary asset holdings by comparing long-run averages of foreign assets, and we compute Kimball's (1990) welfare-based measure of the value of precautionary savings (the equivalent precautionary premium, EPP).

\footnotetext{
${ }^{5}$ We also study a scenario with a two-step interest rate function in which the country pays the EMBI rate if $b<0$ but earns only the T-bill rate if $b \geq 0$. The results are reported later in this Section.
} 
EPP measures a deterministic change in income that equates the marginal utility of assets in a deterministic model with that of the corresponding stochastic model. Following Aiyagari (1994), under CRRA utility $E P P=(1+\gamma) \sigma_{c}^{2} / 2$, where $\sigma_{c}^{2}$ is the coefficient of variation in consumption. EPP is also related to Lucas's (1987) welfare cost of business cycles, $W$, measured as the permanent increase in consumption that makes agents with CRRA utility indifferent between consumption fluctuations of $\sigma_{c}^{2}$ and consumption with zero variability. In particular, $W=\gamma E P P /(1+\gamma)$. This result suggests that $E P P$ may not be very useful in our analysis because $W$ is quite small as long as consumption is trend stationary (see Lucas, 1987), and thus EPP is likely to be small as well. Indeed, our results show that $E P P$ is very small even when precautionary asset holdings are quite large. ${ }^{6}$

\subsection{Baseline Results}

Table 4 lists the moments that characterize the stochastic steady state of the model under the baseline calibration. The table also shows results for higher output autocorrelation $\left(\rho_{y}=0.7\right)$, higher and lower variability in output innovations $\left(\sigma_{e}=4\right.$ and 2 percent, which yield $\sigma_{y}=5$ and 2.5 percent respectively) and higher risk aversion $(\gamma=5)$.

The business cycle moments listed in the Baseline column of Table 4 are standard findings in intertemporal models of small open, endowment economies with incomplete asset markets. Consumption is slightly less volatile than output, and it displays positive correlation with GDP and positive serial autocorrelation. Because precautionary asset demand is the main driving force of foreign asset dynamics in the model, however, the cyclical behavior of net exports and the current account is counterfactual. In particular, both external accounts are strongly positively correlated with output, whereas actual business cycles display countercyclical external accounts. We show in Section 3 that this result is reversed in the two-sector model with production.

The key results in Table 4 are the estimates of precautionary savings. In the Baseline with UE preferences, precautionary savings measure nearly 2.5 percent of GDP, and in the $\mathrm{BAH}$ setup they are nearly 4 times larger at 9.6 percent of GDP. In contrast, EPP is only about 0.15 of a percent in both cases. The cyclical behavior of foreign assets under each preference specification shows important differences. In particular, foreign assets fluctuate significantly more, are less correlated with output, and display higher serial autocorrelation in the UE setup than in the BAH setup. This result occurs because, even though both the $\mathrm{BAH}$ and UE setup reach the same long-run average of $b$ in the Baseline, the BAH setup features an ad-hoc debt limit of 51 percent of GDP, and the probability of hitting that limit in the long run is 10.2 percent, whereas the UE setup attains a stochastic steady-state characterized by a well-behaved symmetric distribution. Notice also that these sharp differences in the long-run distributions of assets in the two setups are driven by small differences in subjective discount factors. On average, the discount factors of the BAH and UE setup are the same, and in the UE setup, the standard deviation of the endogenous discount factor is very small, at about 4 percent of the variability of output. This endogenous discount factor, however, is negatively correlated with GDP (because consumption is procyclical) and its fluctuations are highly persistent.

\footnotetext{
${ }^{6}$ Note also that Kimball's EPP applies to a two-period model without borrowing limits, whereas this paper deals with infinite-horizon economies facing credit constraints.
} 
Table 4 shows that changes in the variability and persistence of output and in the degree of risk aversion preserve the main features of the comparison across the BAH and UE Baseline results. Increases in $\rho_{y}, \sigma_{e}$ and $\gamma$ produce significant increases in precautionary savings, but the BAH setup always produces a larger stock of precautionary savings than the UE specification. The high-risk-aversion case is the one that yields the largest precautionary savings in both setups (10.4 and 23.8 percent of GDP in the UE and BAH specifications, respectively). Note also that both the UE and the BAH setups can generate outcomes in which consumption variability exceeds income variability (by about 8 percent when $\rho_{y}=0.7$ and up to 25 percent in the UE scenario with $\gamma=5$ ). Kose, Prasad and Terrones (2003) identified consumption variability in excess of income variability as a puzzling feature of the data of emerging economies (see also Table 2). Our results suggest that self-insurance under incomplete asset markets may help explain this puzzle.

The high serial autocorrelation coefficients of foreign assets reported in Table 4 indicate that foreign assets converge to their long-run average in a slow, gradual process. This slow convergence is also illustrated in Figure 3, which plots the transitional dynamics of the foreign assets-GDP ratio in the Baseline simulations (in percent relative to long-run averages). The transitional dynamics correspond to the forecast functions of the equilibrium Markov process of $b / y$ conditional on initial conditions for which: (a) $b$ takes the lowest value with positive long-run probability; and (b) the initial income shock is neutral (i.e., $\varepsilon=$ 1). The plots show that convergence to the long-run average of assets takes about 40 years in the BAH setup and more than 80 years in the UE setup. Note, however, that whereas the initial condition for the BAH plot is a foreign assets-GDP ratio nearly 10 percentage points below the long-run average (which corresponds to the debt limit, $\phi$ ), with a long-run probability of 10.2 percent, the initial condition for the UE plot is a ratio nearly 48 percentage points below the long-run average and with a long-run probability of only 0.1 percent. Hence, the initial conditions defined by the criterion of "lowest positive long-run probability" are quite different.

\subsection{Self-Insurance and Business Cycle Volatility}

How much do changes in the cyclical variability of output affect foreign assets positions? Figure 4a shows the increase in precautionary savings as $\sigma_{e}$ rises so that the standard deviation of GDP rises from 1 to 8 percent (keeping $\rho_{y}$ constant). Figure $4 \mathrm{~b}$ is a similar plot but for increases in $\rho_{y}$ from 0 to 0.8. In this case, we keep $\sigma_{e}$ constant but the standard deviation of GDP still increases as its autocorrelation rises (since $\sigma_{y}^{2}=\sigma_{\varepsilon}^{2} /\left(1-\rho_{y}^{2}\right)$ ).

Figure 4a indicates that increases in output variability produce large increases in precautionary demand for foreign assets regardless of the preferences specification (although the BAH setup always yields higher precautionary savings than the UE setup). Figure $4 \mathrm{~b}$ displays similar qualitative results when the autocorrelation of GDP rises, but quantitatively the effects on precautionary savings are weaker. If we examine the long-run averages of foreign asset-GDP ratios instead of precautionary savings, the UE setup produces larger (or smaller) mean asset positions than the BAH setup at lower (or higher) levels of output variability, but the elasticity of the average assets-GDP ratio to changes in the variability and persistence of output is higher with $\mathrm{BAH}$ preferences than with UE preferences. 
The Baseline calibration assumes that the interest rate is the EMBI country risk rate for all values of $b$. This is unrealistic because countries hold their foreign reserves mainly in the form of short-term U.S. treasury bills, which pay a lower real interest rate, and a lower interest rate on saving than on borrowing can affect precautionary asset demand. To explore this issue, we modify the model to introduce a two-step interest rate function: $R=R^{H}=$ 1.059 if $b<0$ and $R=R^{L}=z(1.059)+(1-z) 1.0174$ if $b \geq 0$, for $1 \geq z \geq 0$. Hence, the country pays the EMBI rate on debt, but it earns only a rate between the EMBI rate and the T-bill rate of 0.0174 on positive asset holdings (1.74 percent is the annualized real interest rate on three-month U.S. T-bills for the 1985-2004 period deflated with the U.S. CPI). The case with $z=1$ is our Baseline scenario, and we explore also $z=0.93$ and 0 . The results in Figure 5 show that the increases in mean asset holdings and precautionary savings in response to higher output variability are the same as in the Baseline for output standard deviations of up to 4 percent. Above 4 percent, mean asset holdings and precautionary savings are smaller with $z=0.93$ or 0 than in the Baseline (about half as large for $z=0$ ). It is still the case, however, that higher output variability leads to a large buildup of precautionary savings. ${ }^{7}$ Even at $z=0$, an increase from 4 to 8 percent in output variability increases precautionary holdings of foreign assets by about 10 percentage points of GDP.

The data and the quantitative findings reported here cast serious doubt on the hypothesis that foreign reserves have increased because of increased output variability. Figure $4 \mathrm{~b}$ indicates that the model with UE (or BAH) preferences needs an increase in output volatility of more than 4 (or 1.5) percentage points to account for the observed surge in reserves. But Table 2 shows that output volatility is lower in the post-globalization period in more than half of the Sudden Stop countries. Moreover, Figure 2 shows that the mean and median standard deviation of output, using 20-year rolling windows, have changed slightly within the 3 to 4.5 percent range, and in fact, they have been in a steady decline since the late 1990s. Even for the subset of countries where volatility rose, only in the extreme cases of Peru and Thailand (which show the largest increases in volatility of about 3.5 percentage points before and after Globalization) we find evidence of volatility increases of the magnitude that can account for the observed increases in reserves. Hence, higher longrun business cycle volatility is not a plausible explanation of the surge in reserves - and even less so if we consider the scenario with a two-step interest rate function.

\subsection{Financial Globalization as a Policy Change}

We study next the effects of financial globalization on foreign asset holdings. As shown in Figure 1, the removal of government barriers to global asset trading was a key factor behind financial globalization. Hence, we introduce into the model a time-invariant distortionary tax on foreign asset returns at rate $\tau$ that represents the combined effect of all capital controls. The revenue or outlays generated by this "effective tax" (depending on

\footnotetext{
${ }^{7}$ Figure 5 does not show results for the UE setup because this requires a two-step function for the time-preference elasticity $\rho^{U E}$. Without it, asset holdings when $b \geq 0$ are on a trajectory that aims to converge to a much lower long-run average of $b$ than the calibration target of $b=-0.44$. This implies very strong impatience effects because the rate of time preference is too high relative to $R^{\mathrm{L}}$ and positive bond holdings are very far from the long-run average. Still, the main finding that higher volatility cannot explain the surge in reserves would hold because the two-step adjustments in $R$ and $\rho^{U E}$ would lead to lower mean assets and precautionary savings than in the Baseline.
} 
whether the asset position is positive or negative) are rebated to agents as a lump sum transfer $T_{t}=b_{t} r \tau$, but agents take $T_{t}$ as given. Thus, the agents' budget constraint is now $c_{t}=\varepsilon_{t} y-b_{t+1}+b_{t}[1+r(1-\tau)]+T_{t}+A$. The resource constraint remains as in Eq. (2). Since this tax distorts the competitive equilibrium, the numerical solution method needs to be modified accordingly (see Durdu, Mendoza and Terrones, 2007 for details). We consider tax rates ranging from 0 to 27 percent, and we adjust the calibration so that at a zero tax the $\mathrm{BAH}$ setup approaches the complete-markets equilibrium (i.e., we set $\beta=1 / R$ ). Hence, in this case, the lack of financial integration (i.e., nonzero values of $\tau$ ) represents also the "severity" of market incompleteness, as reflected in the gap between the tax-adjusted rate of time preference and the world real interest rate. Note that in this case, $\beta[1+r(1-\tau)]<1$.

Figure $6 \mathrm{a}$ and $6 \mathrm{~b}$ plot the long-run averages of foreign assets and precautionary savings against the tax on capital flows. For the BAH setup, we show curves for three values of $\phi$ : 10.88 (the natural debt limit), -2 , and -1 . The latter two imply limits of -200 and -100 percent of average GDP respectively. As the tax approaches zero, $b$ and precautionary savings go to infinity because we approach $\beta R=1$. Conversely, at high tax rates the relationship between taxes and mean asset holdings vanishes as the economy spends most of the time at the debt limit. This occurs at tax rates in excess of 10 percent for all three scenarios of $\phi$. In contrast, at tax rates between 0.5 and 10 percent, the BAH setup predicts that the long-run average $b / y$ ratio increases sharply as the tax falls even by small amounts. Thus, this setup predicts that in the early stages of financial globalization, foreign assets respond little to the opening of the capital account, while later on, further financial integration efforts that imply small changes in $\tau$ produce large changes in the long-run average of $b / y$. These effects are the strongest if $\phi$ is the natural debt limit. In this case, a cut in $\tau$ from 8 to 0.5 percent increases the mean $b / y$ ratio from -10 times GDP to about 154 percent of GDP, and precautionary savings rise from 81 percent to about 9.4 times GDP! But the effects are still large with tighter debt limits. With $\phi=-1$, the same tax cut increases average $b / y$ from -90 percent to a positive position of about 20 percent of GDP, and precautionary savings rise from 10 to 120 percent of GDP.

The effects of financial globalization on foreign assets are also large with UE preferences. In this case, cutting $\tau$ from 8 to 0.5 percent increases the long-run average of foreign assets from -156 percent of GDP to almost -45 percent of GDP. Conversely, precautionary savings are approximately unchanged. This result highlights a key difference between the BAH and UE preference specifications: when $\tau$ changes, the UE setup separates the savings effect resulting from the increase in the post-tax return on assets even without uncertainty (i.e., the deterministic steady state of $b$ rises as $\tau$ falls because the return to savings rises and the rate of time preference adjusts accordingly), from the effect due solely to precautionary savings (i.e., the effect on the excess of mean foreign asset holding in the stochastic model relative to the deterministic steady state). In the BAH setup the two effects cannot be separated because the deterministic steady state is invariant to the tax (without uncertainty assets fall until they hit $\phi$ for any $\tau>0$ ).

\subsection{Financial Globalization as a Reduction in Transactions Costs}

Significant innovations in transactions and information technologies are also an important driving force of financial globalization. These innovations have lowered sharply 
the costs associated with financial asset trading. We study this form of financial globalization by introducing into the model a standard quadratic cost of transactions. The economy's resource constraint becomes $c=\varepsilon y-b^{\prime}+b(1+r)-\frac{\varphi}{2}\left(b^{\prime}-b\right)^{2}+A$ for $\varphi \geq 0$.

Modeling financial globalization in this form has some appealing technical features. First, since transactions costs are a feature of the technology, the competitive equilibrium is not distorted, and hence it can be solved easily using the same Bellman Eq. (4) with the new resource constraint. Second, the deterministic stationary equilibria under both UE and BAH preferences, and the natural debt limit under the latter, are unaffected by the transactions costs. Third, because the deterministic steady states are independent of $\varphi$, the asymmetry in the effects of financial globalization on foreign assets under the two formulations of preferences that blurred the analysis of cuts in taxes on capital inflows is not an issue.

The effect of reductions in $\varphi$ on precautionary savings is generally in line with the results obtained for reductions in $\tau$ (see Figure 7 ). In the BAH setup, financial globalization due to lower transactions costs produces large increases in precautionary savings. It is also still the case that when globalization begins (i.e., at high values of $\varphi$ ), the effect of reductions in transactions costs is negligible, but as globalization progresses, the effect of further cost reductions is large. Moreover, in the UE setup precautionary savings do not change much when $\varphi$ changes, as was the case for changes in $\tau$. The one aspect in which the results with $\varphi$ and $\tau$ differ is that the long-run average of $b$ is not affected by the reduction in transactions costs, since transactions costs vanish at the long-run average.

Our results suggest that financial globalization modeled as a policy action and/or a technological innovation can be an important force driving the increase in foreign reserves in Sudden Stop economies (and in emerging economies in general). However, this analysis is subject to two important caveats. First, whether financial globalization is a good explanation of the surge in reserves depends on the timing and magnitude of the cuts in $\tau$ and $\varphi$. The results indicate that if Sudden Stop economies have moved closer to a regime of unrestricted global asset trading (as the indicators in Figure 1 suggest), the expected increases in foreign assets can be easily as large as those observed in the data. Second, the choice of preferences also matters. Precautionary savings rise sharply as $\tau$ or $\varphi$ fall in the BAH setup, but they remain largely unchanged in the UE setup. With UE preferences, a large cut in $\tau$ leads to a large increase in mean foreign assets as the result of the increased incentives for saving, even without uncertainty. Hence, in this case UE preferences could account for the rise in foreign reserves, but not because of precautionary savings.

\section{Two-Sector Production Economy}

\subsection{Structure of the Model}

The two-sector model differs from the one-sector model in four key respects:

(I) Consumption includes tradable goods $\left(c^{T}\right)$ and nontradable goods $\left(c^{N}\right)$ with aggregate consumption defined by a constant-elasticity-of-substitution (CES) function:

$$
c\left(c_{t}^{T}, c_{t}^{N}\right)=\left[a\left(c_{t}^{T}\right)^{-\mu}+(1-a)\left(c_{t}^{N}\right)^{-\mu}\right]^{-\frac{1}{\mu}}, \quad a>0, \mu \geq-1
$$


The elasticity of substitution between tradables and nontradables is given by $1 /(1+\mu)$, and the CES weighting factor is given by $a$.

(II) Nontradable goods are produced by a representative firm using imported intermediate goods $(m)$ as the single variable input of a neoclassical production technology:

$$
y_{t}^{N}=z_{t} Z m_{t}^{\alpha}, \quad 0 \leq \alpha \leq 1 .
$$

$Z$ represents the trend level of total factor productivity (TFP) and it includes the effects of any fixed factors, $z_{t}$ is a stochastic TFP shock, and $\alpha$ is the share of imported inputs in gross output. The firm maximizes profits $\pi_{t}^{N}=p_{t}^{N} y_{t}^{N}-p^{m} m_{t}$. The market of nontradable goods and the world market of intermediate goods are competitive, and thus the profitmaximizing demand for imported inputs is given by a standard marginal productivity rule:

$$
p_{t}^{N} \alpha z_{t} Z m_{t}^{\alpha-1}=p^{m}
$$

In this expression, $p^{m}$, which is kept constant for simplicity, represents the world price of imported inputs relative to tradables, and $p_{t}^{N}$ denotes the price of nontradables relative to tradables, which is determined inside the small open economy. At equilibrium, this price matches the household's marginal rate of substitution between tradables and nontradables:

$$
p_{t}^{N}=\left(\frac{1-a}{a}\right)\left(\frac{c_{t}^{T}}{c_{t}^{N}}\right)^{1+\mu}
$$

(III) The economy has new budget and resource constraints. The budget constraint of households in the competitive equilibrium is:

$$
c_{t}^{T}+p_{t}^{N} c_{t}^{N}=\varepsilon_{t}^{T} y^{T}+A^{T}+\pi_{t}^{N}+p_{t}^{N} A^{N}-b_{t+1}+b_{t} R
$$

Households take profits and the price of notradables as given. Profits at equilibrium are positive and equal to 1- $\alpha$ of nontradables GDP in units of tradables (i.e., gross output minus the cost of intermediate goods). The endowment of tradables is stochastic, so the economy now faces two shocks, one hitting tradables output and one hitting TFP in nontradables. Given the firm's optimality condition (7), the definition of profits, and market clearing in the nontradables sector, it follows that the sectoral resource constraints are as follows:

$$
\begin{gathered}
c_{t}^{T}=\varepsilon_{t}^{T} y^{T}-b_{t+1}+b_{t}(1+r)+A^{T}-p^{m} m_{t} \\
c_{t}^{N}=y_{t}^{N}+A^{N}
\end{gathered}
$$

Constraint (10) imposes liability dollarization because $b$ is in units of tradables.

(IV) We follow Mendoza (2005) in considering the possibility that agents face a collateral constraint in credit markets. In particular, lenders limit credit to a fraction $\kappa$ of the market value of the total income of domestic agents in units of tradables, and up to a maximum $\Omega$ :

$$
b_{t+1} \geq-\kappa\left[\varepsilon_{t}^{T} y^{T}+\pi_{t}^{N}\right] \geq \Omega
$$


The value of income in the center of (12) is equal at equilibrium to the economy's total GDP valued at tradables goods prices, so (12) can be viewed as a constraint on the economy's debt-to-GDP ratio. ${ }^{8}$ The constraint is endogenous, however, because the bond position and the price and production of nontradables are endogenous, and there is feedback between borrowing decisions and the value of nontradables GDP (as explained below).

It is critical to note that this model features a credit-market externality by which individual choices affect the economy's ability to borrow (see Uribe, 2006 and Korinek, 2007). Agents do not internalize the effect of their consumption and bond decisions on the equilibrium price, and therefore the effects of changes in the equilibrium price and production of nontradables on the ability to borrow are also not internalized.

\subsection{Equilibrium and Amplification with Debt-Deflation}

The characteristics of the equilibrium of the one-sector economy described in 2.2 extend to the two-sector economy. In particular, the CES aggregator preserves the Inada condition that makes period marginal utility go to infinity as $c^{T}$ or $c^{N}$ go to zero from above. The natural debt limit that rules out this outcome is $b_{t+1} \geq-\min \left(\varepsilon_{t}^{T} y^{T}+A^{T}-p^{m} m_{t}\right) / r .{ }^{9}$ Because tradables income is only a fraction of total income, this natural debt limit is tighter than the one in the one-sector economy. The agents may also face a higher degree of market incompleteness inasmuch as there is no vehicle to self-insure directly against the risk of fluctuations in nontradables income. Endogenous changes in the price and output of nontradables, however, can provide implicit insurance depending on how substitutable are tradables and nontradables in consumption (i.e., on the value of $\mu$ ) and on the equilibrium correlation between nontradables and tradables income.

The collateral constraint (12) introduces a borrowing limit that is "occasionally binding." In the states of nature in which this constraint binds, the Euler equation for tradables consumption is:

$$
U_{c^{T}}(t)=\exp \left[-v\left(C\left(c_{t}^{T}, c_{t}^{N}\right)\right)\right] E_{t}\left[U_{c^{T}}(t+1) R\right]+\eta_{t}
$$

As Mendoza (2005, 2006a) explains, the Lagrange multiplier $\eta_{t}$ can be interpreted as an endogenous premium that lenders charge borrowers to ensure that the credit constraint is not violated. In turn, the justification for the constraint could be limited contract enforcement by which lenders can confiscate only $\kappa$ of a defaulting borrower's income.

Suppose that the economy has just enough debt so that a pair of shocks $\left(z_{t}, \varepsilon_{t}^{T}\right)$ of standard magnitude triggers the credit constraint. Tradables consumption falls because agents cannot borrow as much as they wanted. In turn, at the "initial" level of nontradables output, the decline in tradables consumption makes the price of nontradables fall. But as this price falls, so does the value of the marginal product of imported inputs, and hence

\footnotetext{
${ }^{8}$ This formula rules out equilibria in which the constraint could be satisfied at very high debt levels that prop up $c^{T}$ and $p^{N}$.(see Mendoza (2005) for details).

${ }^{9}$ Note that agents take profits and the price of nontradables as given, so their individual natural debt limit is $b_{t+1} \geq-\min \left(\varepsilon_{t}^{T} y^{T}+A^{T}+\pi_{t}^{N}+p_{t}^{N} A^{N}\right) / r$. With this debt limit, however, there could still be equilibrium sequences where tradables consumption is nonpositive. The resource constraint (10) implies that at equilibrium, the natural debt limit must be $b_{t+1} \geq-\min \left(\varepsilon_{t}^{T} y^{T}+A^{T}-p^{m} m_{t}\right) / r$.
} 
demand for these inputs and the output of nontradables fall. Up to this point, the credit transmission mechanism is similar to the one widely studied in Sudden Stop models with balance sheet effects (e.g., Calvo, 1998). If the price and output of nontradables fall, however, the value of the total income in units of tradables falls, tightening the constraint further and setting in motion Fisher's (1933) debt-deflation amplification mechanism. ${ }^{10}$

The possibility of Sudden Stops strengthens precautionary savings incentives. ${ }^{11}$ Agents make optimal self-insurance plans taking into account the endogenous link between choices of foreign asset holdings and the magnitude and likelihood of Sudden Stops. As a result, the economy builds a buffer stock of savings so as to minimize the risk of landing in debt positions large enough for a Sudden Stop to cause massive consumption collapses.

The equilibrium of the two-sector economy in recursive form is characterized by a decision rule for $t+1$ foreign assets, $b^{\prime}\left(b, \varepsilon^{T}, z\right)$, as a deterministic function of date- $t$ assets and the date-t realization of shocks, that solves the following Bellman equation:

$$
\begin{aligned}
V\left(b, \varepsilon^{T}, z\right)=\max _{b^{\prime}, m}\left\{\begin{array}{r}
{\left[\frac{\left.\left[a\left(c_{t}^{T}\right)^{-\mu}+(1-a)\left(c_{t}^{N}\right)^{-\mu}\right]^{-\frac{1}{\mu}}\right]^{1-\gamma}}{1-\gamma}+\right.} \\
\exp \left(-v\left(\left[a\left(c_{t}^{T}\right)^{-\mu}+(1-a)\left(c_{t}^{N}\right)^{-\mu}\right]-\frac{1}{\mu}\right)\right) E\left[V\left(b^{\prime}, \varepsilon^{T^{\prime}}, z^{\prime}\right)\right]
\end{array}\right\} \\
\text { subject to } \quad c^{T}=\varepsilon^{T} y^{T}-b^{\prime}+b R+A^{T}-p^{m} m \\
c^{N}=z Z m^{\alpha}+A^{N} \\
b^{\prime} \geq-\kappa\left[\varepsilon^{T} y^{T}+(1-\alpha) p^{N} z Z m^{\alpha}\right]
\end{aligned}
$$

As in the case of the one-sector model, we solve this Bellman equation using value function iteration methods. There are, however, important modifications that are needed in order to handle the two-sector structure of the model and the endogenous credit constraint (see Durdu, Mendoza and Terrones, 2007 for details).

\subsection{Calibration}

The baseline calibration parameters for the two-sector economy are listed in Table 3 . Mendoza (2002) calibrated a model with tradables and nontradables for Mexico using sectoral data, so our calibration follows closely his. We keep the values $\gamma=2, b=-0.44$ and $R=1.059$ from the calibration of the one-sector model. The steady-state relative price of nontradables, the world price of intermediate goods and total GDP in units of tradables are normalized to $p^{N}=1, p^{m}=1$ and $y^{T}+p^{N} y^{N}-p^{m} m=1$. Hence, the steady-state allocations can be interpreted as ratios relative to total GDP in units of tradables. We use the same elasticity-of-substitution parameter as Mendoza's, $\mu=0.316$, which corresponds to an

10 Mendoza (2005) provides an illustrative deterministic example. He shows that the Fisherian deflation converges to a unique equilibrium that amplifies balance sheet effects significantly.

${ }^{11}$ Aizenman and Lee (2007) derive an analytical result with similar features in a Diamond-Dybvigstyle model. They show that a discrete liquidity shock increases the need for precautionary savings. 
estimate for Mexico obtained by Ostry and Reinhart (1992). We also set steady-state sectoral consumption and production ratios to match the following averages calculated by Mendoza using Mexican data at current prices: The ratio of nontradables-to-tradables GDP is $\left(p^{N} y^{N}-p^{m} m\right) / y^{T}=1.543$, which given $p^{N}=p^{m}=y^{T}+p^{N} y^{N}-p^{m} m=1$ implies that $y^{T}=$ $1 /(1+1.543)=0.393$ and $\left(p^{N} y^{N}-p^{m} m\right)=1.543 /(1+1.543)=0.607$. The sectoral consumptionGDP ratios are $c^{T} / y^{T}=0.665$ and $p^{N} c^{N} /\left(p^{N} y^{N}-p^{m} m\right)=0.71$. These ratios and the values of tradables and nontradables GDP imply that $c^{T}=0.261$ and $c^{N}=0.431$.

The share of imported input costs to gross output of nontradables is $\alpha=0.2$. In the deterministic steady state, this factor share yields a ratio of imported inputs to total GDP of 13 percent, which matches the ratio for Mexico reported in Mendoza (2006b). With $\alpha=0.2$ and the GDP of nontradables calculated above, gross output of nontradables (i.e., nontradables GDP plus imported inputs) is equal to $0.61 /(1-\alpha)=0.758$. It follows then that the trend level of TFP in nontradables is equal to $Z=0.758^{1-\alpha} / \alpha^{\alpha}=1.106$ and then condition (7) implies that the steady-state level of imported inputs is $m=(\alpha Z)^{1 /(1-\alpha)}=0.152$.

The value of $a$ in the CES aggregator is set so that $p^{N}=1$ given the values of $\mu, c^{T}$, and $c^{N}$. This requires $a=0.341$. As in the one-sector model, we introduce constant lump-sum levels of exogenous absorption $A^{T}$ and $A^{N}$ to make the model consistent with observed expenditure shares. In particular, $A^{T}=y^{T}+b r-m-c^{T}=-0.046$ and $A^{N}=y^{N}-c^{N}=0.328$.

The time preference elasticity in the UE setup is $\rho^{U E}=\ln (R) / \ln \left(1+C\left(c^{T}, c^{N}\right)\right)=0.1867$. This implies the same steady-state subjective discount factor as in the one-sector model (0.944). In the BAH setup, we set $\phi=-0.7$ and $\beta=0.94395$ (or $\rho^{B A H}=0.0594$ ) so as to match Mexico's mean of net foreign assets and variability of aggregate consumption.

The data necessary to construct a reliable estimate of TFP shocks in the nontradables sector are not available. Hence, we followed Mendoza (2006b) in using a two-stage "identification-by-simulation" strategy: In the first stage, we proxy TFP shocks in nontradables with nontradables GDP, and use THQA to construct a Markov process for $\varepsilon^{T}$ and $z$ to approximate a $\operatorname{VAR}(1)$ estimated with the HP-filtered cyclical components of tradables and nontradables GDP from Mexican data for period 1965-2005. The nontradables sector is defined as services plus industry minus manufacturing. The VAR model is $y_{t}=\rho \cdot y_{t-1}+e_{t}$ where $y_{t}{ }^{\prime}=\left[y_{t}^{T} y_{t}^{N}\right], \rho$ is a $2 \times 2$ matrix of autocorrelation coefficients, and $e_{t}{ }^{\prime}$ $=\left[e_{t}^{T} e_{t}^{N}\right]$ is a vector of error terms with variance-covariance matrix cova $(e)$. The estimates of $\rho$ and $\operatorname{cova}(e)$ are:

$$
\rho=\left[\begin{array}{cc}
1.088^{*} & 0.564^{*} \\
-0.655^{*} & 0.154
\end{array}\right], \quad \operatorname{cova}(e)=\left[\begin{array}{ll}
0.000601 & 0.000472 \\
0.000472 & 0.000572
\end{array}\right]
$$

An asterisk denotes coefficients that are statistically significant at the 99 percent confidence level. Interestingly, the VAR results indicate that most of the persistence in the fluctuations of nontradables GDP follows from spillovers from tradables GDP (because the autocorrelation term for nontradables GDP is not significantly different from zero).

The unconditional standard deviations of tradables and nontradables output in the data are $\sigma_{y^{T}}=0.0336$ and $\sigma_{y^{N}}=0.0327$, the first-order autocorrelations are $\rho_{y^{T}}=0.575$ and 
$\rho_{y^{N}}=0.603$, and the correlation between the two is $\rho_{y^{T}, y^{N}}=0.772$. Passing the estimates in (15) to the TQHA program and using three realizations for $\varepsilon^{T}$ and $z$ (which imply nine $\left(\varepsilon^{T}, z\right.$ ) pairs), we obtain a Markov process that, after solving the model, produces standard deviations of 0.0301 and 0.0246 for GDP of tradables and nontradables respectively. The sectoral GDP serial autocorrelations are 0.539 for tradables and 0.577 for nontradables, and the correlation between the two is equal to 0.791. Thus, using nontradables GDP as a proxy for nontradables TFP we obtained a Markov process that approximates well the actual cyclical behavior of each sector's GDP, except that the variability of nontradables GDP (which is endogenous in the model) is underestimated - the model yields 2.46 percent instead of 3.27 percent in the data.

The second stage of the identification process adjusts the elements of $\rho$ and cova $(e)$ that involve nontradables TFP so as to produce a baseline simulation of the model that yields a closer approximation to the unconditional moments of tradables and nontradables GDP in the data (particularly the standard deviation of the latter). We left unchanged the elements of $\rho$ that were statistically significant in the results reported in (15). The closest approximation to the moments in the data produces the following unconditional moments: $\hat{\sigma}_{y^{T}}=0.0334, \quad \hat{\sigma}_{y^{N}}=0.0305, \quad \hat{\rho}_{y^{T}}=0.587, \quad \hat{\rho}_{y^{N}}=0.483$, and $\hat{\rho}_{y^{T}, y^{N}}=0.516$, and the following VAR structure for tradables GDP and nontradables TFP:

$$
\rho=\left[\begin{array}{cc}
1.088 & 0.564 \\
-0.655 & 0.300
\end{array}\right], \quad \operatorname{cova}(e)=\left[\begin{array}{cc}
0.000601 & 0.00055 \\
0.00055 & 0.0012
\end{array}\right]
$$

\subsection{Baseline Results}

Table 5 reports the business cycle moments that characterize the stochastic steady state of the two-sector model. Consumption of tradables is less volatile than tradables output, and consumption of nontradables, for which there is no storage technology that can be used to smooth consumption, is more volatile than nontradables output. Aggregate consumption in units of tradables is less volatile than output (also in units of tradables) with UE preferences, but more volatile than output with BAH preferences. Both consumption and output in units of tradables are more volatile with BAH preferences than with UE preferences.

In terms of matching key characteristics of actual business cycles, the two-sector model improves upon the one-sector model in two important respects: First, it produces countercyclical fluctuations in the current account and net exports. The correlations of the current account-output ratio with output in units of tradables are -0.14 and -0.48 with UE and $\mathrm{BAH}$ preferences, respectively. Hence, agents build up debt in the expansion phase of the business cycle, which is an important feature of debt dynamics in emerging economies. Second, the model is also in line with the data in predicting large, procyclical, and persistent fluctuations in the relative price of nontradables (i.e., the real exchange rate).

The two-sector model is consistent with the one-sector model in predicting that precautionary savings are larger in the BAH setup than in the UE setup (25.3 percent of the long-run average of GDP in the former vs. 1.6 percent in the latter). Moreover, comparing across the one-sector and two-sector models, the UE setup shows that precautionary savings are lower in the two-sector economy (2.5 percent in the one-sector model vs. 1.6 percent in 
the two-sector model). Precautionary savings in the BAH one-sector and two-sector Baseline economies are not comparable because they were calibrated with different values of $\phi$. We show below, however, that with common $\phi$ 's the BAH setup also predicts that precautionary savings are generally smaller in the two-sector model than in the one-sector model.

\subsection{Revisiting the Effects of Output Variability $\mathcal{G}$ Financial Globalization on Foreign Assets}

The conclusions derived from the one-sector model regarding the effects of business cycle volatility and financial globalization on foreign assets extend to the two-sector model. In the model, increases in the variability of tradables output and/or nontradables TFP can lead to large increases in the long-run average of foreign assets. The data, however, do not show evidence of sufficiently large increases in the variability of output of Sudden Stop countries. Table 2 shows that volatility in the nontradables sector has increased only in a few of the Sudden Stop countries, with the median showing virtually no change. On the other hand, the variability of tradables GDP increased in most Sudden Stop countries, but only in five of them are the increases of the size that the model with either BAH or UE preferences would need to predict large changes in reserves. Moreover, given the downward trend visible in the rolling standard deviations of aggregate output in Figure 2, it is possible that these increases in the variability of tradables GDP are a transitory phenomenon.

Figure 8 shows the effects of financial globalization on the long-run average of foreign assets and on precautionary savings in the two-sector model. We also include plots for the one-sector model for comparison. The two main results from the one-sector model are preserved: (1) financial globalization yields large increases in the mean foreign asset position, which increases at a linear rate with UE preferences, and at a sharply increasing rate in the BAH setup; (2) precautionary savings also rise at a fast increasing rate in the BAH setup while they are nearly invariant to the degree of financial globalization in the UE setup.

Comparing across one- and two-sector models we find that with BAH preferences both the long-run average of foreign assets and precautionary savings are uniformly smaller in the two-sector economy. With UE preferences, however, mean foreign assets are smaller in the one-sector model at levels of barriers to capital mobility equivalent to taxes of 10 percent or more. At lower taxes the one- and two-sector models with UE preferences predict about the same long-run averages of foreign assets. By contrast, precautionary savings are uniformly smaller in the two-sector UE setup. Despite these differences, the effects of financial globalization on mean foreign assets and precautionary saving remain large, particularly as financial globalization approaches the full removal of barriers to international asset trading.

The smaller precautionary savings effects in the two-sector model reflect the fact that the equilibrium correlation between tradables income and nontradables income valued at tradables goods prices is negative (at about -0.4 in both UE and BAH setups). Hence, when the economy suffers a negative shock to tradables GDP, the value of nontradables income

rises, providing an implicit hedge that reduces the need for precautionary savings. Since $y^{T}$ and $y^{N}$ are positively correlated, the negative correlation between $y^{T}$ and $p^{N} y^{N}$ is driven by the negative correlations between $p^{N}$ and the output of each sector. These price correlations depend on the elasticity of substitution between tradadables and nontradables in consumption and on the response of the supply of nontradable goods, which depends on technology parameters and the price of imported inputs. 


\subsection{Self-Insurance against Sudden Stops: How large should the war chest be?}

We move now to quantify the changes in precautionary demand for foreign assets induced by Sudden Stop risk. We consider a baseline scenario with $\kappa=0.5$. Table 5 shows the business cycle moments in the stochastic steady state. A standard finding from the debtdeflation models of Sudden Stops is that long-run business cycle statistics are not altered significantly by credit constraints. A comparison of the moments with and without credit constraints in Table 5 shows that this is the case here as well. Hence, the model's endogenous Sudden Stops are infrequent (but positive probability) events nested within "normal" business cycles.

The long-run average of assets in the BAH (UE) setup increases from -44.7 (-42.4) percent without Sudden Stop risk to -24.3 (-37.8) percent when Sudden Stops are possible. Since in the UE setup the deterministic stationary state of foreign assets is the same with or without credit constraints, precautionary savings with UE preferences increase by the same amount as the long-run average of foreign assets: $-37.8-(-42.4)=4.6$ percent. Thus, with UE preferences the risk of Sudden Stops leads to an increase in precautionary asset holdings of about 4.6 percent of long-run GDP.

Quantifying the change in precautionary savings with BAH preferences is less obvious because the debt limit (which is also the debt to which the economy converges in the long run in the absence of uncertainty) changes from -0.7 without Sudden Stop risk to -0.5 with Sudden Stop risk. The long-run average of foreign assets rises 20.4 percentage points of GDP from one scenario to the other, but since the credit limit itself rises by 20 percentage points, the overall change in precautionary savings is only about $1 / 2$ of a percentage point. Hence, relative to the corresponding credit limits, precautionary savings are about the same with or without Sudden Stop risk in the BAH setup. However, if we consider the buildup of precautionary asset holdings from the perspective of an economy where Sudden Stop risk has just been introduced, the model predicts that agents would need to enlarge their war chest of foreign assets by 20.4 percentage points of GDP in the long-run. This "transitional" measure of the extra precautionary savings that need to be accumulated as a result of the structural change implied by the introduction of Sudden Stop risk is a better measure of the effect that the first waves of Sudden Stops of the 1990s should have on self-insurance behavior according to the BAH setup.

Figure 9 illustrates Sudden Stop dynamics. The plots illustrate the amplification and persistence of the response of the model's endogenous variables to shocks of standard magnitude when the credit constraint binds. To be precise, the plots show the differences in percentage deviations from long-run averages in the economy with credit constraints relative to the economy with perfect credit markets in response to initial negative shocks to tradables output and nontradables TFP, and conditional on an initial debt ratio at which the credit constraint binds. The shocks are the pair $\left(\varepsilon^{T}, z\right)$ in the Markov chain that yields the closest approximation to one-standard-deviation shocks. ${ }^{12}$ The initial foreign asset position is -48.7 percent of long-run GDP. The probability of reaching this debt ratio in the long run is 0.9 (1.1) percent in the BAH (UE) setup.

${ }^{12}$ Because the discrete Markov chain is not a perfect approximation, the shocks are equivalent to 1.25 and 1.05 times the standard deviation of tradables output and nontradables TFP, respectively. 
The foreign assets plot illustrates the dynamics of precautionary savings. Initially, both $\mathrm{BAH}$ and UE setups show negative values because the initial foreign assets (-0.487) are smaller than the corresponding long-run averages by a larger gap when credit constraints are present than when they are absent. In the UE setup the gap is about -4 percentage points of GDP initially, whereas in the BAH setup the gap is nearly five times larger in absolute value. This result reflects the smaller change in mean foreign assets relative to perfect credit markets in the UE setup. In terms of persistence, foreign assets take a long time to converge. In the BAH setup, a gap of about -4 percentage points of GDP still remains after 50 years. In contrast, the negative gap closes in about 5 years in the UE setup, but after that point the gap climbs to 1.5 percent and returns to zero very slowly. This moderate "overshooting" of the asset position is an implication of the endogenous rate of time preference.

The plots in Figure 9 illustrate the ability of the debt-deflation mechanism to produce Sudden Stops in response to one-standard-deviation shocks. Qualitatively, the features of the Sudden Stops are identical in the BAH and UE setups: a current account reversal, a collapse in the price of nontradables, and declines in sectoral and aggregate consumption and output, all of which represent amplified responses to the shocks induced by the Fisherian debt deflation. Quantitatively, the BAH setup produces larger Sudden Stops than the UE setup.

The transitional dynamics in Figure 9 show that Sudden Stop economies can go through prolonged periods in which they buildup foreign assets, display persistent current account surpluses, and maintain undervalued real exchange rates. These "imbalances" gradually grow smaller over time. The qualitative features of this adjustment are consistent with the recent experience of several Sudden Stop countries, particularly in Asia. Moreover, the current account surplus and undervalued real exchange rate are by-products of the buildup of precautionary savings in the aftermath of Sudden Stops, or following financial globalization. They do not require intentional exchange rate management by central banks.

The plots in Figure 9 illustrate Sudden Stops for an initial condition of $b$ of -48.7 percent of mean GDP. Many other debt positions, however, also trigger Sudden Stops. Figure 10 shows the current account reversals and price collapses that occur on impact when negative one-standard-deviation $\varepsilon^{T}$ and $z$ shocks hit the economy at different initial conditions of $b$. For $b \geq-0.482$, the credit constraint does not bind and hence there is zero amplification and no Sudden Stops. For $-0.578<b<-0.482$, the constraint binds and there are Sudden Stops. This Sudden Stop region can be split into two parts. One part includes Sudden Stops that are so large (with current account reversals of up to 100 percentage points of GDP) that precautionary savings rules them out in the long run. In Figure 10, this part of the Sudden Stop region is defined by values of $b$ to the left of the long-run probability borders of the UE and BAH setups (which are located at about the 50 percent debt ratio in both cases). The second part of the Sudden Stop region is on the right side of these borders. That is the "long-run Sudden Stop region," where Sudden Stops with positive long-run probability occur. This region includes the case illustrated in Figure 9 as well as other Sudden Stop episodes that produce effects more than twice as large. ${ }^{13}$ The cumulative long-run probability of all Sudden Stop states is 3.88 (7.85) percent in the BAH (UE) setup.

${ }^{13}$ The initial condition $b / y=-0.487$ used in Figure 9 is very close to the region where the credit constraint does not bind, so it yields a moderate Sudden Stop (but still with quantitative features that are close to the magnitudes observed in actual Sudden Stops). 
Once the economy hits a Sudden Stop, how long does it take for precautionary accumulation of foreign assets to provide enough self-insurance to minimize the probability of returning to that debt position? The answer to this question can be derived from the transitional CDFs of foreign assets for the BAH and UE setups starting from the initial asset position that generated the Sudden Stop shown in Figure 9 (-48.7 percent of GDP). The probability of reaching this debt ratio is minimized when the economy reaches the stochastic steady state (as noted before, the long-run probabilities of $b=-0.487$ are 1.1 and 0.9 percent in the UE and BAH setups respectively). The transitional CDFs for the BAH and UE setups show that this process takes more than 15 years. After two years, the probability of hitting again the -48.7 percent debt ratio is 21 percent in the UE setup and 40 percent in the BAH setup. After 15 years, the probability is 3.4 percent in the UE setup and 4.7 percent in the BAH setup. Thus, the model predicts that precautionary savings provide substantial selfinsurance to reduce the probability of Sudden Stops sharply in the long run, but the process of building up this war chest of assets is long and gradual.

\section{Conclusions}

This paper examines the recent surge in foreign reserves in Sudden Stop countries from the perspective of a dynamic, stochastic general equilibrium framework of optimal precautionary demand for foreign assets. This framework allows for two formulations of preferences with different implications for self-insurance behavior (the Bewley-AiyagariHugget setup and the Uzawa-Epstein setup). We use this framework to study a one-sector endowment economy and a two-sector production economy with "liability dollarization" (i.e., debt denominated in units of tradables but leveraged partly on the income from the nontradables sector). The two-sector model features a credit constraint that produces endogenous Sudden Stops driven by Irving Fisher's debt-deflation mechanism. When the constraint binds, the price and income of the nontradables sector collapse, thereby reducing further the agents' ability to borrow. As a result, the responses of macroeconomic variables to shocks of standard magnitude show significant amplification and persistence.

Three key mechanisms drive precautionary asset demand in the framework studied in this paper: the cyclical variability of output, international financial integration, and Sudden Stop risk. Our quantitative analysis shows that all three mechanisms can produce large changes in foreign asset holdings. Output variability cannot explain the surge in reserves, however, because output variability has not increased in Sudden Stop countries. By contrast, financial integration and Sudden Stop risk produce large increases in foreign assets that are comparable to observed surges in reserves, and the data do show that financial globalization and the emergence of Sudden Stop risk coincided with the buildup of reserves.

We also found that the adjustments in foreign assets and key macroeconomic aggregates triggered by financial globalization and Sudden Stop risk follow a gradual process with persistent current account surpluses and undervalued real exchange rates. The probability of Sudden Stops declines slowly as it takes more than 50 years to attain its minimum level in the long run. In addition, financial globalization progresses in nonlinear fashion under BAH preferences. In the early stages, large changes in barriers to global asset trading produce small changes in foreign assets, but as a regime of perfect capital mobility is approached, small changes in barriers to asset trading cause large changes in asset positions. 
The two-sector production economy can account for two features of the data that are often hard to explain: countercyclical fluctuations in the external accounts and large, persistent fluctuations in the real exchange rate. In addition, this model features an implicit hedging mechanism because tradables income and nontradables income in units of tradables are negatively correlated at equilibrium. As a result, the buffer stocks of assets implied by precautionary savings are smaller in the two-sector model than in the one-sector model. This outcome, however, depends on features of preferences and technology that drive the correlation between tradables and nontradables incomes and the price of nontradables.

One caveat of our analysis is that we abstracted from sovereign default. Alfaro and Kanczuk (2006) showed, however, that given the choice of a portfolio of "defaultable debt" and reserve assets in the form of risk-free bonds, the optimal choice is to hold zero reserves. Default considerations, therefore, do not seem useful for explaining the surge in reserves.

Precautionary demand for foreign assets arises from distortions on financial markets, and hence it is suboptimal. This raises two important normative questions that we did not address in the paper: What are the welfare costs that result from these distortions? And, are there policy strategies that can yield superior outcomes. The literature sheds some light on these questions. On one hand, the classic Lucas result showing that the welfare cost of consumption volatility in representative-agent models with CRRA utility is negligible, regardless of the asset market structure and as long as growth and business cycles are unrelated, suggests that the overall welfare cost of precautionary savings should be small. Likewise, international RBC models predict that the cost of moving from perfect world capital markets to financial autarky is negligible. On the other hand, Durdu and Mendoza (2006) showed that welfare costs conditional on a Sudden Stop state are high. They also found, however, that attempting to prevent these Sudden Stops with a credit facility that aims to defuse the debt-deflation process can result in distortions with even larger costs, unless the facility functions with a complex state-contingent policy. Caballero and Panageas (2006) showed that precautionary savings can be undesirable for emerging economies that hope to attain higher long-run growth rates, and in this case arrangements that provide financing when Sudden Stops hit are welfare-improving. If we move away from the representative-agent paradigm, the costs of precautionary savings and financial globalization for countries with underdeveloped financial systems can be large, and distributed regressively across the population (see Mendoza et al., 2007).

In the final analysis, we conclude that the argument behind the New Mercantilism is only partially correct. On one hand, our findings do show that the aim to minimize Sudden Stop risk can lead to a surge in foreign asset holdings. On the other hand, the New Mercantilism cannot be defended by arguing that business cycle volatility has increased, because this is not observed in the data. The New Mercantilism also fails inasmuch as frameworks like ours, or the one developed by Mendoza et al. (2007) predict that financial globalization can be a strong driving force of the rise in reserves. Self-insurance behavior is part of the mechanism by which globalization affects foreign asset holdings in those models, but not because of a desire to build a war chest for defense against Sudden Stops. Instead, it is a consequence of the removal of barriers to global asset trading given the underdevelopment of the financial markets that agents in emerging economies can access. 


\section{References}

Aiyagari, S. Rao (1994). "Uninsured Idiosyncratic Risk and Aggregate Saving." Quarterly Journal of Economics, vol. 109, No. 3, pp. 17-31.

Aizenman, Joshua and Jaewoo Lee (2007). "International Reserves: Precautionary Versus Mercantilist Views, Theory and Evidence." Open Economies Review, forthcoming.

Alfaro, Laura and Fabio Kanczuk (2006). "Optimal Reserve Management and Sovereign Debt." Draft, Harvard Business School.

Caballero, Ricardo and Stavros Panageas, (2006), "Hedging Sudden Stops and Precautionary Contractions," Journal of Development Economics, forthcoming.

Calvo, Guillermo A. (1998). "Capital Flows and Capital-Market Crises: The Simple Economics of Sudden Stops." Journal of Applied Economics, v.1, pp 35-54.

Calvo, Guillermo A., Alejandro Izquierdo, and Luis Mejia (2004). "On the Empirics of Sudden Stops: The Relevance of Balance-Sheet Effects." National Bureau of Economic Research Working Paper No. 10520; MA: Cambridge.

Cavallo, Eduardo, and Jeffrey Frankel (2004). "Does Openness to Trade Make Countries More Vulnerable to Sudden Stops, or Less? Using Gravity to Establish Causality." Draft. John F. Kennedy School of Government, Harvard University. Cambridge: MA.

Chinn, Menzie, and Hiro Ito (2005). "What Matters for Financial Development? Capital Controls, Institutions, and Interactions." Journal of Development Economics, forthcoming.

Choi, Woon Gyu, and David Cook (2003). "Liability Dollarization and the Bank Balance Sheet Channel." Journal of International Economics, vol. 64(2), pp. 247-275.

Choi, Woon Gyu, Sunil Sharma, and Maria Stromqvist (2007). "Capital Flows, Financial Integration, and International Reserve Holdings: The Recent Experience of Emerging Markets and Advanced Economies." IMF Working Paper.

Dooley, Michael, David Folkerts-Landau, and Peter Garber (2003). "An essay on the revived Bretton Woods System." Working Paper No. 9971; Cambridge, MA: National Bureau of Economic Research.

Durdu, C. Bora (2007). "Quantitative Implications of Indexed Bonds in Small Open Economies." International Finance Discussion Papers 910. Washington D.C.: Board of Governors of the Federal Reserve System.

Durdu, C. Bora, and Enrique G. Mendoza (2006). "Are Asset Price Guarantees Useful for Preventing Sudden Stops?: The Globalization Hazard-Moral Hazard Tradeoff of Asset Price Guarantees." Journal of International Economics, Vol. 69, pp. 84-119.

Durdu, C. Bora, Enrique G. Mendoza and Marco E. Terrones (2007). "Precautionary Demand for Foreign Assets in Sudden Stop Economies: An Assessment of the New Mercantilism." Working Papers 13123; Cambridge, MA: NBER.

Edwards, Sebastian (2005). "Capital Controls, Sudden Stops and Current Account Reversals." Working Paper No. 11170. ; Cambridge, MA: National Bureau of Economic Research.

Epstein, Larry G. (1983). "Stationary Cardinal Utility and Optimal Growth under Uncertainity." Journal of Economic Theory, Vol. 31, pp. 133-152.

Fisher, Irving (1933), "The Debt-Deflation Theory of Great Depressions," Econometrica 1, 337-57.

Fogli, Alessandra, and Fabrizio Perri (2006). "The Great Moderation and the US External Imbalances." Working Papers 12708; Cambridge, MA: NBER. 
Hugget, Mark (1993). "The Risk Free Rate in Heterogenous-Agent, Incomplete-Insurance Economies." Journal of Economic Dynamics and Control, Vol. 17, No. 5-6, pp. 953-969.

Jeanne, Olivier (2007). "International Reserves in Emerging Markets Countries: Too Much of a Good Thing?" forthcoming, Brookings Papers in Economic Activity.

Jeanne, Olivier, and Romain Rancière (2006). "The Optimal Level of International Reserves for Emerging Market Countries: Formulas and Applications." IMF Working Paper No. 06/229, Washington, D.C.: International Monetary Fund.

Kimball, Miles S. (1990), "Precautionary Saving in the Small and in the Large," Econometrica, v. 58, No. 1, pp. 53-73.

Korinek, Anton (2007). "Excessive Dollar Borrowing in Emerging Markets: Balance Sheet Effects and Macroeconomic Externalities." Draft, Columbia University.

Kose, Ayhan, Eswar Prasad, and Marco Terrones (2003). "Financial Integration and Macroeconomic Volatility," IMF Staff Papers, Vol. 50, Special Issue, pp. 119-142.

Lane, Philip R., and Gian Maria Milesi-Ferretti (2006). "The External Wealth of Nations Mark II: Revised and Extended Estimates of Foreign Assets and Liabilities, 1970-2004." IMF Working Paper No. 06/69, Washington, D.C.: International Monetary Fund.

Ljungqvist, Lars, and Thomas J. Sargent (2004). Recursive Macroeconomic Theory, Cambridge, MA: MIT Press.

Lucas Jr., Robert E. (1987), Models of Business Cycles, Basil-Blackwell.

Mendoza, Enrique G. (2002). "Credit, Prices, and Crashes: Business Cycles with a Sudden Stop." In Preventing Currency Crises in Emerging Markets, Frankel, Jeffrey and Sebastian Edwards eds. Chicago: University of Chicago Press.

Mendoza, Enrique G. (2005). "Real Exchange Rate Volatility and the Price of Nontradables in Sudden-Stop Prone Economies." Economia, fall, pp. 103-148.

Mendoza, Enrique G. (2006a). "Lessons from the Debt-Deflation Theory of Sudden Stops." Working Paper No. 11966; Cambridge, MA: National Bureau of Economic Research.

Mendoza, Enrique G. (2006b). "Endogenous Sudden Stops in a Business Cycle Model with Collateral Constraints: A Fisherian Deflation of Tobin's Q." Working Paper No. 12564; Cambridge, MA: National Bureau of Economic Research.

Mendoza Enrique G., and Linda Tesar (1998). "The International Ramifications of Tax Reforms; Supply-Side Economics in a Global Economy." American Economic Review, Vol. 88, pp. 226-245.

Mendoza, Enrique G,. Vincenzo Quadrini, and Jose Victor Rios-Rull (2007). "Financial Integration, Financial Deepness and Global Imbalances." Working Paper No. 12909; Cambridge, MA: National Bureau of Economic Research.

Ostry, Jonathan D. and Carmen M. Reinhart (1992), "Private Saving and Terms of Trade Shocks," IMF Staff Papers, 39, 495-517.

Rothenberg, Alexander, and Francis E. Warnock (2006). "Sudden Flight and True Sudden Stops." Working Paper No. 12726; Cambridge, MA: NBER.

Tauchen, George, Robert Hussey (1991). "Quadrature-based Methods for Obtaining Approximate Solutions to Nonlinear Asset Pricing Models." Econometrica, Vol. 59, No. 2, pp. 371-396.

Uribe, Martin (2006). "Individual Versus Aggregate Collateral Constraints and the Overborrowing Syndrome." Working Paper No. 12260; Cambridge, MA: NBER.

Uribe, Martin, and Zhanwei Vivian Yue (2006). "Country Spreads and Emerging Countries: Who Drives Whom?" Journal of International Economics, Vol. 69, pp. 6-3 
Table 1. International Reserve Position in Sudden Stop Economies ${ }^{1 /}$ (Percent of GDP)

\begin{tabular}{lcccc}
\hline Country & $\begin{array}{c}\text { Year of Sudden } \\
\text { Stop }^{2 /}\end{array}$ & Before $^{3 /}$ & After & Difference \\
& & & & \\
\hline Argentina I & 1994 & 3.20 & 8.62 & 5.42 \\
Argentina II & 2001 & 5.04 & 11.54 & 6.51 \\
Brazil & 1998 & 4.36 & 7.65 & 3.30 \\
Chile & 1998 & 16.93 & 20.49 & 3.57 \\
Colombia & 1998 & 9.24 & 12.21 & 2.97 \\
Ecuador & 1999 & 7.35 & 3.89 & -3.46 \\
Hong Kong & 1998 & 34.16 & 68.85 & 34.69 \\
Indonesia & 1997 & 6.53 & 18.69 & 12.17 \\
Korea & 1997 & 5.03 & 21.26 & 16.23 \\
Mexico & 1994 & 4.64 & 7.29 & 2.65 \\
Malaysia & 1997 & 25.18 & 39.54 & 14.36 \\
Pakistan & 1998 & 1.90 & 8.51 & 6.61 \\
Peru & 1998 & 9.25 & 16.66 & 7.41 \\
Philippines & 1997 & 6.05 & 16.69 & 10.65 \\
Russia & 1998 & 3.05 & 12.46 & 9.41 \\
Thailand & 1997 & 14.84 & 28.01 & 13.17 \\
Turkey & 2001 & 5.67 & 13.57 & 7.90 \\
Uruguay & 2002 & 7.18 & 20.06 & 12.87 \\
& & & & \\
Median & & 6.29 & 15.12 & 7.66 \\
Median Asian Countries & 6.53 & 21.26 & 13.17 \\
& & & & \\
\hline I Refers to the & & & & \\
\hline
\end{tabular}

${ }^{1 /}$ Refers to the emerging market economies that experienced a sudden stop during the past two-decades.

${ }^{2 /}$ We include Sudden Stop episodes that are included in various empirical studies of Sudden Stops, such as Calvo, et. al. (2004), Cavallo and Frankel (2004), and Rothenberg and Warnock (2006).

${ }^{3 /}$ Covers the period since 1985 to the year before the sudden stop.

${ }^{4 /}$ Covers the period since the year after the sudden stop till 2004. 
Table 2. Output Variability and Financial Globalization ${ }^{1 /}$

\begin{tabular}{|c|c|c|c|c|c|c|c|c|c|c|c|c|}
\hline & \multicolumn{4}{|c|}{ Output } & \multicolumn{4}{|c|}{ Tradable Output } & \multicolumn{4}{|c|}{ Non-tradable Output $^{2 /}$} \\
\hline & \multicolumn{4}{|c|}{$\begin{array}{c}\text { Pre- } \\
\text { Globalization Globalization }\end{array}$} & \multicolumn{4}{|c|}{$\begin{array}{c}\text { Pre- } \\
\text { Globalization Globalization }\end{array}$} & \multicolumn{4}{|c|}{$\begin{array}{c}\text { Pre- } \\
\text { Globalization Globalization }\end{array}$} \\
\hline & Full & $(1)^{3 /}$ & $(2)^{3 /}$ & Ratio (1)/(2) & Full & (1) $)^{3 /}$ & $(2)^{3 /}$ & Ratio $(1) /(2)$ & Full & $(1)^{3 /}$ & $(2)^{3 /}$ & Ratio (1)/(2) \\
\hline \multicolumn{13}{|l|}{ Industrial Countries ${ }^{4 /}$} \\
\hline United States & 1.90 & 2.38 & 1.57 & 1.52 & 3.93 & 4.52 & 3.50 & 1.29 & 1.47 & 1.30 & 1.62 & 0.81 \\
\hline United Kingdom & 1.90 & 2.01 & 2.00 & 1.01 & 4.91 & 6.43 & 3.54 & 1.81 & 2.07 & 2.37 & 1.81 & 1.30 \\
\hline France & 1.22 & 1.13 & 1.49 & 0.76 & 4.19 & 4.97 & 3.62 & 1.37 & 1.24 & 0.88 & 1.48 & 0.60 \\
\hline Germany & 1.68 & 2.02 & 1.51 & 1.34 & 2.82 & 2.54 & 3.07 & 0.83 & 1.44 & 1.57 & 1.38 & 1.14 \\
\hline Japan & 2.62 & 3.29 & 1.98 & 1.66 & 3.68 & 4.06 & 3.75 & 1.08 & 2.51 & 3.23 & 1.68 & 1.92 \\
\hline Mean Industrial Countries & 2.14 & 2.33 & 2.10 & 1.17 & 3.39 & 3.68 & 3.25 & 1.14 & 1.98 & 2.14 & 1.85 & 1.23 \\
\hline Median Industrial Countries & 1.90 & 2.01 & 1.90 & 1.26 & 3.34 & 3.84 & 3.25 & 1.08 & 1.87 & 1.93 & 1.68 & 1.28 \\
\hline \multirow{2}{*}{\multicolumn{13}{|c|}{$\begin{array}{l}\text { Emerging Market } \\
\text { Economies (EME's) }\end{array}$}} \\
\hline & & & & & & & & & & & & \\
\hline \multicolumn{13}{|c|}{ Sudden Stop Countries (SSC) ${ }^{6 /}$} \\
\hline Argentina & 5.48 & 3.46 & 7.20 & 0.48 & 5.48 & 3.93 & 6.92 & 0.57 & 5.24 & 3.81 & 6.54 & 0.58 \\
\hline Brazil & 4.14 & 5.28 & 2.70 & 1.95 & 4.44 & 4.50 & 4.39 & 1.02 & 4.03 & 4.85 & 3.12 & 1.55 \\
\hline Chile & 4.88 & 6.79 & 2.98 & 2.28 & 5.99 & . & 5.99 & . & 3.74 & & 3.74 & \\
\hline Colombia & 2.26 & 2.33 & 2.47 & 0.94 & 4.82 & 2.83 & 6.34 & 0.45 & 3.15 & 2.21 & 3.99 & 0.55 \\
\hline Ecuador & 3.15 & 3.93 & 2.62 & 1.50 & 6.80 & 4.74 & 8.60 & 0.55 & 5.45 & 5.80 & 5.07 & 1.14 \\
\hline Mexico & 3.27 & 3.67 & 3.06 & 1.20 & 3.36 & 3.07 & 3.70 & 0.83 & 3.27 & 3.53 & 3.00 & 1.18 \\
\hline Peru & 5.19 & 3.51 & 7.13 & 0.49 & 5.74 & 4.72 & 7.38 & 0.64 & 5.05 & 3.32 & 6.94 & 0.48 \\
\hline Uruguay & 5.45 & 6.48 & 5.25 & 1.24 & 5.98 & 6.41 & 6.46 & 0.99 & 5.80 & 6.88 & 5.59 & 1.23 \\
\hline Hong Kong & 3.50 & 3.78 & 3.12 & 1.21 & 5.33 & & 5.33 & & 2.06 & & 2.06 & \\
\hline Indonesia & 4.11 & 2.81 & 5.32 & 0.53 & 3.02 & 2.55 & 3.56 & 0.72 & 5.30 & 3.91 & 6.74 & 0.58 \\
\hline Korea & 3.19 & 3.36 & 2.90 & 1.16 & 4.59 & 5.11 & 4.17 & 1.22 & 2.79 & 2.74 & 2.84 & 0.97 \\
\hline Malaysia & 3.54 & 2.64 & 4.66 & 0.57 & 4.17 & 3.33 & 4.81 & 0.69 & 4.58 & 3.23 & 5.28 & 0.61 \\
\hline Pakistan & 2.18 & 2.63 & 1.72 & 1.53 & 2.62 & 3.27 & 2.22 & 1.47 & 2.49 & 3.02 & 1.47 & 2.06 \\
\hline Philippines & 3.33 & 4.16 & 2.88 & 1.44 & 3.08 & 3.78 & 2.74 & 1.38 & 3.98 & 5.06 & 3.25 & 1.56 \\
\hline Thailand & 4.23 & 2.44 & 5.97 & 0.41 & 4.03 & 2.88 & 5.42 & 0.53 & 4.76 & 2.96 & 6.59 & 0.45 \\
\hline Turkey & 3.52 & 3.40 & 4.06 & 0.84 & 3.44 & 3.12 & 3.75 & 0.83 & 3.72 & 4.06 & 3.50 & 1.16 \\
\hline Mean SSC & 3.84 & 3.79 & 4.00 & 1.11 & 4.56 & 3.87 & 5.11 & 0.85 & 4.09 & 3.95 & 4.36 & 1.01 \\
\hline Median SSC & 3.53 & 3.48 & 3.09 & 1.18 & 4.52 & 3.56 & 5.07 & 0.77 & 4.00 & 3.67 & 3.87 & 1.06 \\
\hline Mean EME's & 3.77 & 3.75 & 3.64 & 1.22 & 4.51 & 4.04 & 4.82 & 0.93 & 4.22 & 4.37 & 3.67 & 1.44 \\
\hline Median EME's & 3.53 & 3.57 & 3.09 & 1.18 & 4.43 & 3.78 & 4.28 & 0.83 & 3.93 & 3.91 & 3.38 & 1.14 \\
\hline
\end{tabular}

\footnotetext{
Figures are percent standard deviations of the (HP-filtered) cyclical components of each series.

${ }^{2 /}$ The non-tradable output is proxied as the sum of value added in services and industry minus the value added in manufacturing, in real terms.

${ }^{3 /}$ Pre-Globalization and Globalization refer to the $1966-1985$ and 1986-2005 periods, respectively.

${ }^{4 /}$ Refers to the twenty one most advanced economies.

${ }^{5 /}$ Refers to the twenty two largest middle-income economies.

${ }^{6 /}$ See Table 1 for a definition of Sudden Stop countries.
} 
Table 3. Calibration of the one- and two-sector models.

\section{One-sector model}

$\begin{array}{lll}\rho^{B A H} & \text { Rate of time preference in the BAH setup } & 0.064 \\ \rho^{U E} & \text { Rate of time preference elasticity in the UE setup } & 0.944 \\ \gamma & \text { Coefficient of relative risk aversion } & 2.000 \\ \phi & \text { Ad-hoc debt limit } & -0.510 \\ R & \text { Gross world interest rate } & 1.059 \\ y & \text { Mean GDP } & 1.000 \\ c & \text { Consumption-GDP ratio } & 0.692 \\ b & \text { Net foreign assets-GDP ratio } & -0.440 \\ \sigma e & \text { Standard deviation of GDP innovations } & 0.026 \\ \rho & \text { Autocorrelation of GDP } & 0.597 \\ A & \text { Lump-sum absorption } & 0.282\end{array}$

\section{Two-sector model}

$\begin{array}{clc}\rho^{B A H} & \text { Rate of time preference in the BAH setup } & 0.059 \\ \rho^{U E} & \text { Rate of time preference elasticity in the UE setup } & 0.187 \\ \gamma & \text { Coefficient of relative risk aversion } & 2.000 \\ \mu & \text { Elasticity of substitution } & 0.316 \\ a & \text { CES weight of tradable consumption } & 0.341 \\ \phi & \text { Ad-hoc debt limit } & -0.700 \\ \alpha & \text { Share of imported inputs } & 0.200 \\ R & \text { Gross world interest rate } & 1.059 \\ b^{N} & \text { Net foreign assets-GDP ratio } & -0.440 \\ p^{N} & \text { Relative price of nontradables } & 1.000 \\ p^{m} & \text { Price of imported input } & 1.000 \\ y^{T}+p^{N} y^{N}-p^{m} m & \text { GDP in units of tradables } & 1.000 \\ c^{T} / y^{T} & \text { Tradable consumption-GDP ratio } & 0.665 \\ p^{N} c^{N} /\left(p^{N} y^{N}-p^{m} m\right) & \text { Nontradable consumption-GDP ratio } & 0.710 \\ \left(p^{N} y^{N}-p^{m} m\right) / y^{T} & \text { Nontradable-tradable GDP ratio } & 1.543 \\ A^{T} & \text { Lump-sum absorption of tradables } & 0.106 \\ A^{N} & \text { Lump-sum absorption of nontradables } & 0.176\end{array}$

Note: BAH refers to Bewley-Aiyagari-Hugget, UE refers to Uzawa-Epstein. CES refers to constant elasticity of substitution. 
Table 4. Statistiscal Moments of the Stochastic Steady State of the One-Sector Economy

\begin{tabular}{|c|c|c|c|c|c|c|c|c|c|c|}
\hline & \multicolumn{2}{|c|}{ Baseline } & \multicolumn{2}{|c|}{ Auto Corr 0.7} & \multicolumn{2}{|c|}{$\underline{\text { Std Dev. 5\% }}$} & \multicolumn{2}{|c|}{$\underline{\text { Std Dev. } 2.5 \%}$} & \multicolumn{2}{|c|}{ Risk Aver. 5.0} \\
\hline & UE & $\mathrm{BAH}$ & UE & $\mathrm{BAH}$ & UE & $\mathrm{BAH}$ & UE & BAH & UE & $\mathrm{BAH}$ \\
\hline Precautionary savings, (in percent) & 2.37 & 9.61 & 3.73 & 12.37 & 5.41 & 22.11 & 1.40 & 5.36 & 10.35 & 23.80 \\
\hline \multicolumn{11}{|l|}{ Equivalent Precautionary } \\
\hline Premium, EPP, (in percent) ${ }^{2 /}$ & 0.15 & 0.16 & 0.23 & 0.23 & 0.33 & 0.33 & 0.08 & 0.10 & 0.51 & 0.29 \\
\hline \multicolumn{11}{|l|}{ Means } \\
\hline Output & 1.00 & 1.00 & 1.00 & 1.00 & 1.00 & 1.00 & 1.00 & 1.00 & 1.00 & 1.00 \\
\hline Consumption & 0.69 & 0.69 & 0.69 & 0.70 & 0.70 & 0.70 & 0.69 & 0.69 & 0.70 & 0.70 \\
\hline Foreign assets & -0.42 & -0.42 & -0.41 & -0.39 & -0.39 & -0.30 & -0.43 & -0.46 & -0.34 & -0.28 \\
\hline Trade balance ${ }^{3 /}$ & 0.02 & 0.02 & 0.02 & 0.02 & 0.02 & 0.02 & 0.02 & 0.03 & 0.02 & 0.02 \\
\hline Discount factor & 0.94 & 0.94 & 0.94 & 0.94 & 0.94 & 0.94 & 0.94 & 0.94 & 0.94 & 0.94 \\
\hline \multicolumn{11}{|l|}{$\begin{array}{l}\text { Coefficients of variation (in } \\
\text { percent) }\end{array}$} \\
\hline Output & 3.28 & 3.28 & 3.63 & 3.63 & 4.97 & 4.97 & 2.49 & 2.49 & 3.28 & 3.28 \\
\hline Consumption & 3.13 & 3.26 & 3.92 & 3.92 & 4.72 & 4.66 & 2.38 & 2.59 & 4.11 & 3.11 \\
\hline Foreign assets & 24.41 & 10.11 & 29.73 & 13.39 & 36.97 & 20.28 & 18.52 & 6.33 & 40.92 & 20.10 \\
\hline Current account ${ }^{3 /}$ & 2.68 & 2.02 & 2.77 & 2.08 & 4.08 & 3.42 & 2.03 & 1.40 & 2.81 & 2.48 \\
\hline Trade balance ${ }^{3 /}$ & 3.04 & 2.11 & 3.27 & 2.23 & 4.62 & 3.66 & 2.30 & 1.44 & 3.72 & 2.78 \\
\hline Discount factor & 0.14 & 0.00 & 0.18 & 0.00 & 0.21 & 0.00 & 0.11 & 0.00 & 0.18 & 0.00 \\
\hline \multicolumn{11}{|l|}{$\begin{array}{l}\text { Normalized coefficients of } \\
\text { variation (relative to output) }\end{array}$} \\
\hline Consumption & 0.95 & 0.99 & 1.08 & 1.08 & 0.95 & 0.94 & 0.96 & 1.04 & 1.25 & 0.95 \\
\hline Foreign assets & 7.43 & 3.08 & 8.19 & 3.69 & 7.43 & 4.08 & 7.44 & 2.55 & 12.46 & 6.12 \\
\hline Current account $^{3 /}$ & 0.82 & 0.62 & 0.76 & 0.57 & 0.82 & 0.69 & 0.82 & 0.56 & 0.86 & 0.75 \\
\hline Trade balance ${ }^{3 /}$ & 0.92 & 0.64 & 0.90 & 0.61 & 0.93 & 0.74 & 0.93 & 0.58 & 1.13 & 0.85 \\
\hline Discount factor & 0.04 & 0.00 & 0.05 & 0.00 & 0.04 & 0.00 & 0.04 & 0.00 & 0.06 & 0.00 \\
\hline \multicolumn{11}{|l|}{ Output correlations } \\
\hline Consumption & 0.42 & 0.75 & 0.48 & 0.78 & 0.42 & 0.67 & 0.42 & 0.81 & 0.26 & 0.54 \\
\hline Foreign assets & 0.32 & 0.56 & 0.34 & 0.53 & 0.32 & 0.44 & 0.32 & 0.62 & 0.19 & 0.33 \\
\hline Current account ${ }^{3 /}$ & 0.97 & 0.85 & 0.97 & 0.83 & 0.97 & 0.89 & 0.97 & 0.81 & 0.99 & 0.93 \\
\hline Trade balance $^{3 /}$ & 0.76 & 0.70 & 0.68 & 0.63 & 0.76 & 0.73 & 0.76 & 0.67 & 0.66 & 0.74 \\
\hline Discount factor & -0.42 & 0.00 & -0.48 & 0.00 & -0.42 & 0.00 & -0.42 & 0.00 & -0.26 & 0.00 \\
\hline \multicolumn{11}{|l|}{ Autocorrelations } \\
\hline Output & 0.59 & 0.59 & 0.69 & 0.69 & 0.59 & 0.59 & 0.59 & 0.59 & 0.59 & 0.59 \\
\hline Consumption & 0.97 & 0.84 & 0.97 & 0.88 & 0.97 & 0.88 & 0.97 & 0.81 & 0.99 & 0.93 \\
\hline Foreign assets & 0.99 & 0.96 & 0.99 & 0.98 & 0.99 & 0.98 & 0.99 & 0.94 & 1.00 & 0.99 \\
\hline Current account ${ }^{3 /}$ & 0.57 & 0.51 & 0.67 & 0.62 & 0.57 & 0.54 & 0.57 & 0.49 & 0.59 & 0.56 \\
\hline Trade balance $^{3 /}$ & 0.67 & 0.55 & 0.76 & 0.67 & 0.67 & 0.59 & 0.67 & 0.52 & 0.76 & 0.64 \\
\hline Discount factor & 0.98 & 0.00 & 0.98 & 0.00 & 0.98 & 0.00 & 0.97 & 0.00 & 0.99 & 0.00 \\
\hline
\end{tabular}

\footnotetext{
${ }^{1 /}$ Precautionary savings are measured as defined in the text.

${ }^{2 /}$ The equivalent precautionary premium (EPP) is calculated as follows: $\mathrm{EPP}=(1+\gamma) \sigma_{\mathrm{c}}{ }^{2} / 2$, where $\sigma_{\mathrm{c}}{ }^{2}$ is the coefficient of variation in consumption.

${ }^{3 /}$ Current account and trade balance are measured in percent of output.
} 


\section{Table 5. Statistical Moments of the Stochastic Stationary State of the Two-Sector Economy}

\begin{tabular}{|c|c|c|c|c|}
\hline & \multicolumn{4}{|c|}{ Baseline } \\
\hline & \multicolumn{2}{|c|}{$\mathbf{U E}$} & \multicolumn{2}{|c|}{ ВАН } \\
\hline & $\begin{array}{l}\text { Econ } w / \text { perfect } \\
\text { credit markets }\end{array}$ & $\begin{array}{l}\text { Econ } w / \text { binding } \\
\text { credit constraints }\end{array}$ & $\begin{array}{l}\text { Econ } w / \text { perfect } \\
\text { credit markets }\end{array}$ & $\begin{array}{l}\text { Econ } w / \text { binding } \\
\text { credit constraints }\end{array}$ \\
\hline Precautionary savings, (in percent) ${ }^{1 /}$ & 1.588 & 6.153 & 25.316 & 25.740 \\
\hline \multicolumn{5}{|l|}{ Means } \\
\hline Consumption of tradables & 0.262 & 0.264 & 0.261 & 0.269 \\
\hline Consumption of nontradables & 0.431 & 0.432 & 0.430 & 0.435 \\
\hline Consumption & 0.360 & 0.362 & 0.359 & 0.366 \\
\hline Price of nontradables & 1.005 & 1.011 & 1.003 & 1.027 \\
\hline Net foreign assets & -0.424 & -0.378 & -0.447 & -0.243 \\
\hline Current Account-GDP ratio & 0.000 & 0.000 & 0.000 & 0.000 \\
\hline Tradables GDP & 0.393 & 0.393 & 0.393 & 0.393 \\
\hline GDP in units of tradables & 1.002 & 1.006 & 1.000 & 1.019 \\
\hline Nontradables GDP & 0.607 & 0.608 & 0.606 & 0.610 \\
\hline Imported input & 0.152 & 0.153 & 0.152 & 0.156 \\
\hline \multicolumn{5}{|l|}{ Coefficients of variation (in percent) } \\
\hline Consumption of tradables & 1.643 & 1.523 & 3.139 & 2.993 \\
\hline Consumption of nontradables & 5.369 & 5.379 & 4.926 & 4.896 \\
\hline Consumption & 3.626 & 3.634 & 3.169 & 3.109 \\
\hline Price of nontradables & 6.622 & 6.550 & 8.099 & 8.053 \\
\hline Net foreign assets & 19.824 & 16.436 & 42.960 & 76.574 \\
\hline Current Account-GDP ratio & 1.453 & 1.416 & 1.950 & 1.939 \\
\hline Tradables GDP & 3.345 & 3.345 & 3.345 & 3.345 \\
\hline GDP in units of tradables & 2.213 & 2.184 & 3.292 & 3.271 \\
\hline Nontradables GDP & 3.050 & 3.059 & 2.797 & 2.793 \\
\hline Imported input & 3.805 & 3.688 & 5.846 & 5.754 \\
\hline \multicolumn{5}{|c|}{ Correlation with GDP in units of tradables } \\
\hline Consumption of tradables & 0.374 & 0.341 & 0.804 & 0.803 \\
\hline Consumption $^{\prime \prime}$ & 0.913 & 0.921 & 0.833 & 0.840 \\
\hline Price of nontradables & 0.749 & 0.740 & 0.867 & 0.873 \\
\hline Net foreign assets & 0.266 & 0.151 & 0.437 & 0.408 \\
\hline Current Account-GDP ratio & -0.141 & -0.142 & -0.474 & -0.497 \\
\hline Imported input & 0.833 & 0.826 & 0.929 & 0.931 \\
\hline \multicolumn{5}{|l|}{ First-order autocorrelation } \\
\hline Consumption of tradables & 0.961 & 0.920 & 0.908 & 0.897 \\
\hline Consumption of nontradables & 0.483 & 0.484 & 0.505 & 0.502 \\
\hline Consumption & 0.528 & 0.525 & 0.663 & 0.650 \\
\hline Price of nontradables & 0.460 & 0.451 & 0.489 & 0.485 \\
\hline Net foreign assets & 0.985 & 0.974 & 0.995 & 0.994 \\
\hline Current Account-GDP ratio & 0.489 & 0.477 & 0.456 & 0.455 \\
\hline Tradables GDP & 0.587 & 0.587 & 0.587 & 0.587 \\
\hline GDP in units of tradables & 0.674 & 0.653 & 0.673 & 0.660 \\
\hline Nontradables GDP & 0.483 & 0.484 & 0.505 & 0.502 \\
\hline Imported input & 0.514 & 0.484 & 0.577 & 0.565 \\
\hline \multicolumn{5}{|l|}{$\begin{array}{l}\text { Correlation between tradables and } \\
\text { nontradables incomes (at tradables }\end{array}$} \\
\hline good prices) & -0.357 & -0.338 & -0.373 & -0.378 \\
\hline
\end{tabular}

"Precautionary savings are measured as defined in the text.

${ }^{2 /}$ The correlation is relative to the real GDP, i.e., the sum of tradables plus nontradables GDP not expressed in units of tradables. 
Figure 1. Emerging Market Economies: Financial Globalization
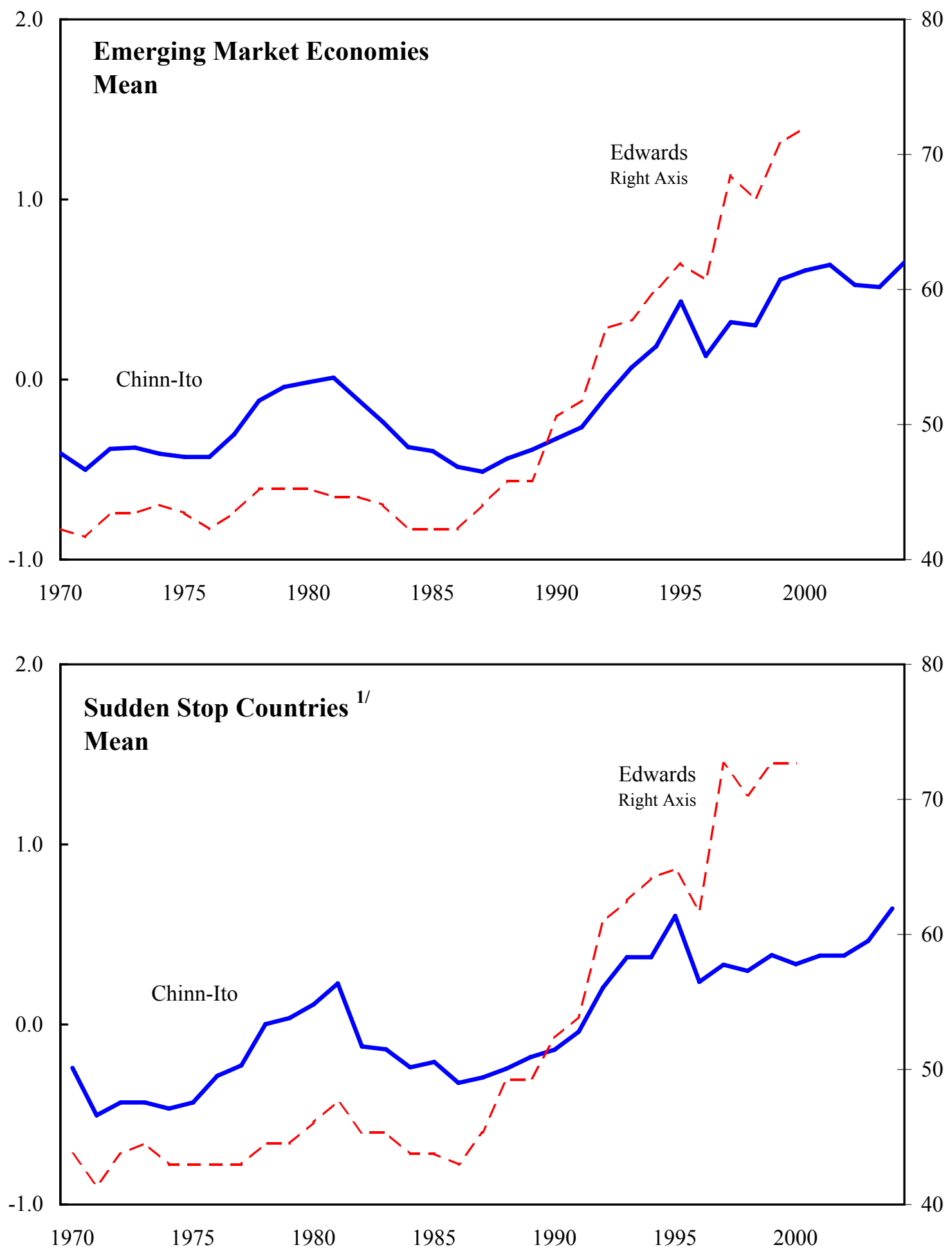

${ }^{1 /}$ See Table 1 for a definition of sudden stop countries. 
Figure 2. Sudden Stop Countries: Rolling Standard Deviation of Output ${ }^{1 /}$ (Percent)
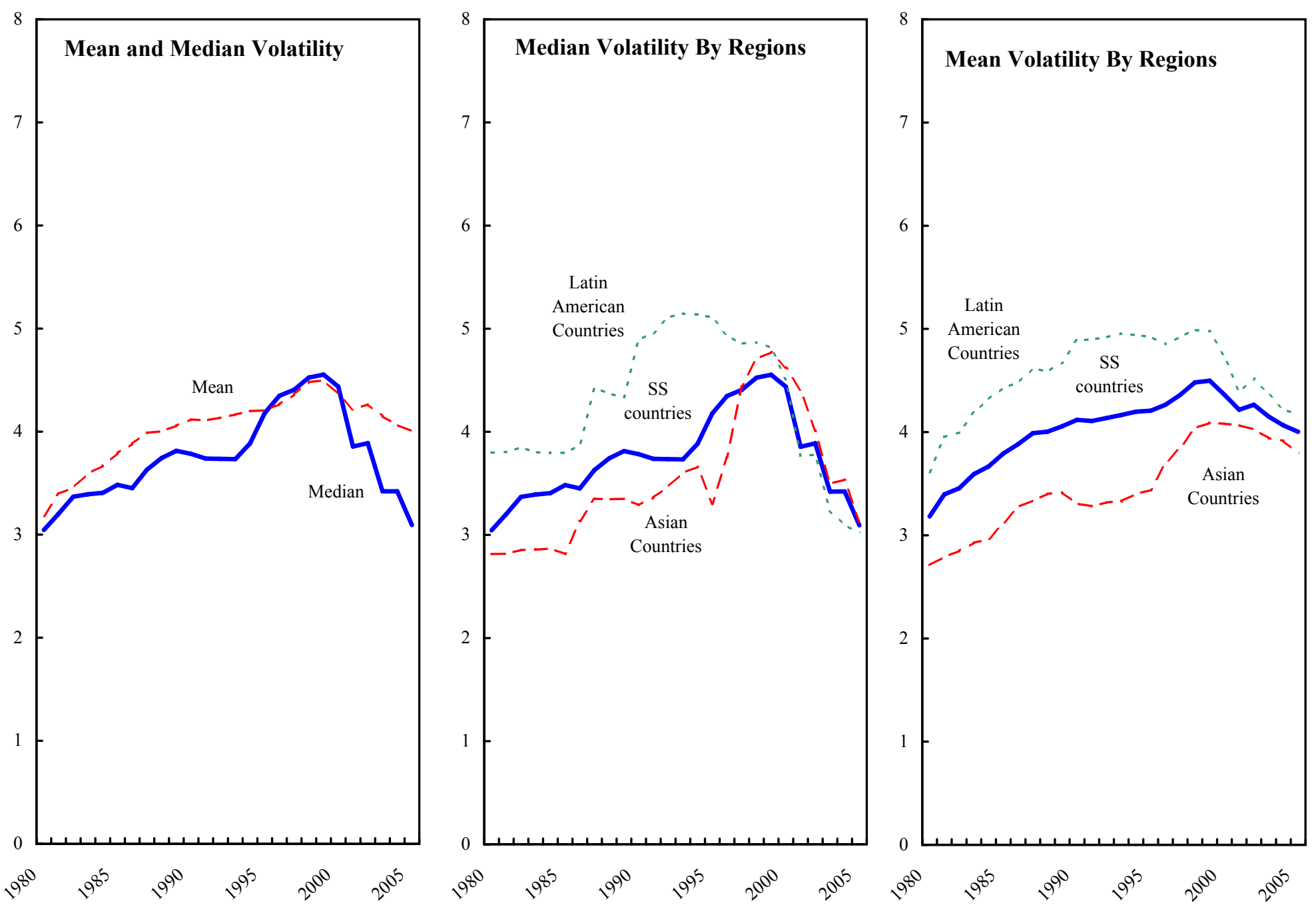

${ }^{1 /}$ Twenty-year rolling standard deviation. See Table 1 for a definition of sudden stop countries. 
Figure 3. One-Sector Model: Transitional Dynamics of Foreign Assets

(Forecast functions conditional on lowest positive probability asset position and neutral shocks at date 1)

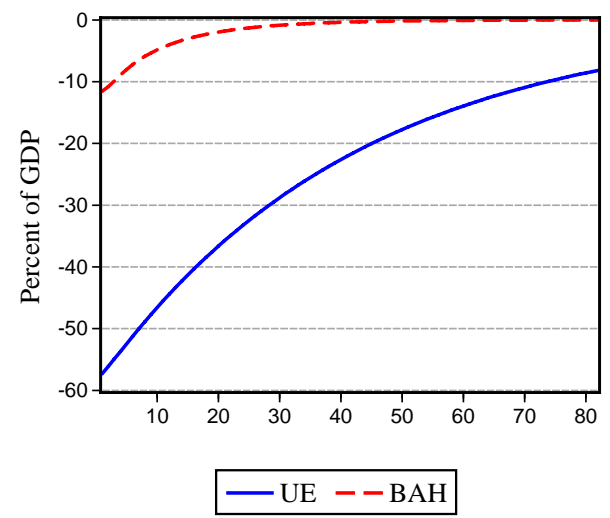

Figure 4. Effects of Variability and Persistence of Output on Precautionary Demand of Foreign Assets
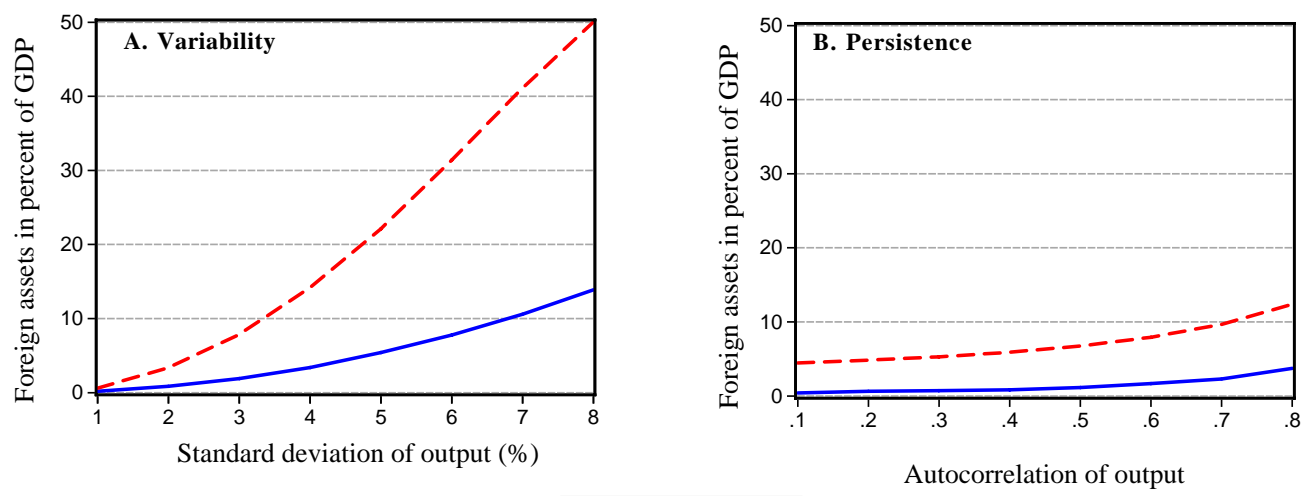

$-\mathrm{UE}--\mathrm{BAH}$

Note: UE refers to Uzawa-Epstein, BAH refers to Bewley-Aiyagari-Hugget 
Figure 5. Effects of Output Volatility on Precautionary Asset Demand with Two-Step Interest Rate Function

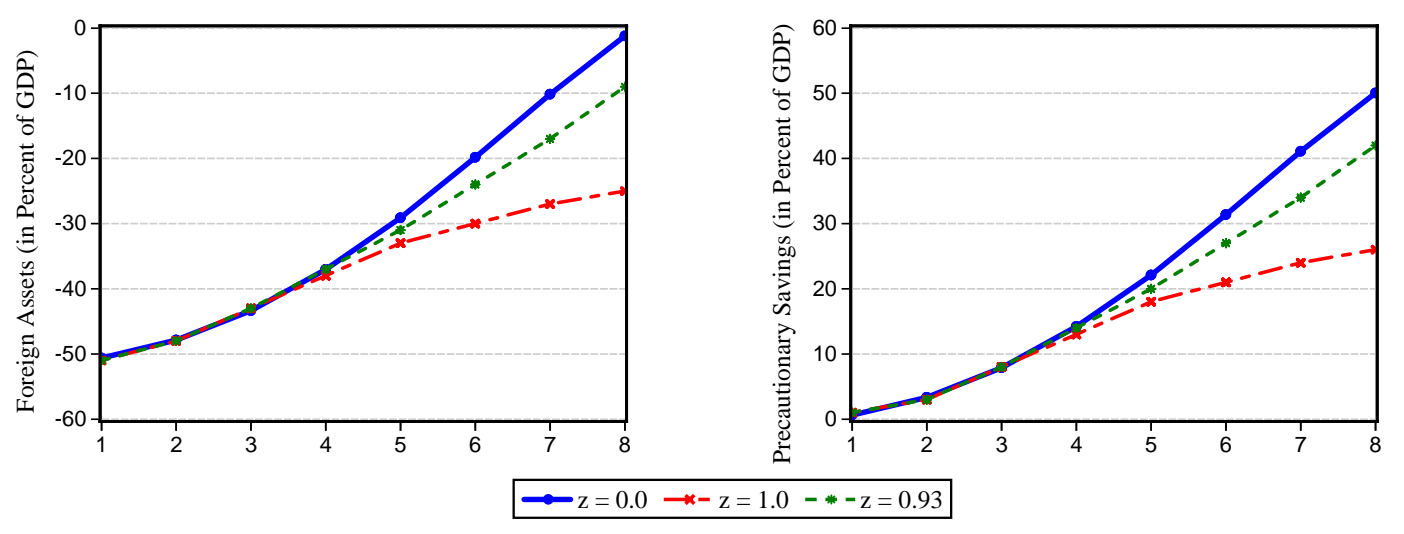

Figure 6. One-Sector Model: Financial Globalization, Foreign Assets, and Precautionary Savings

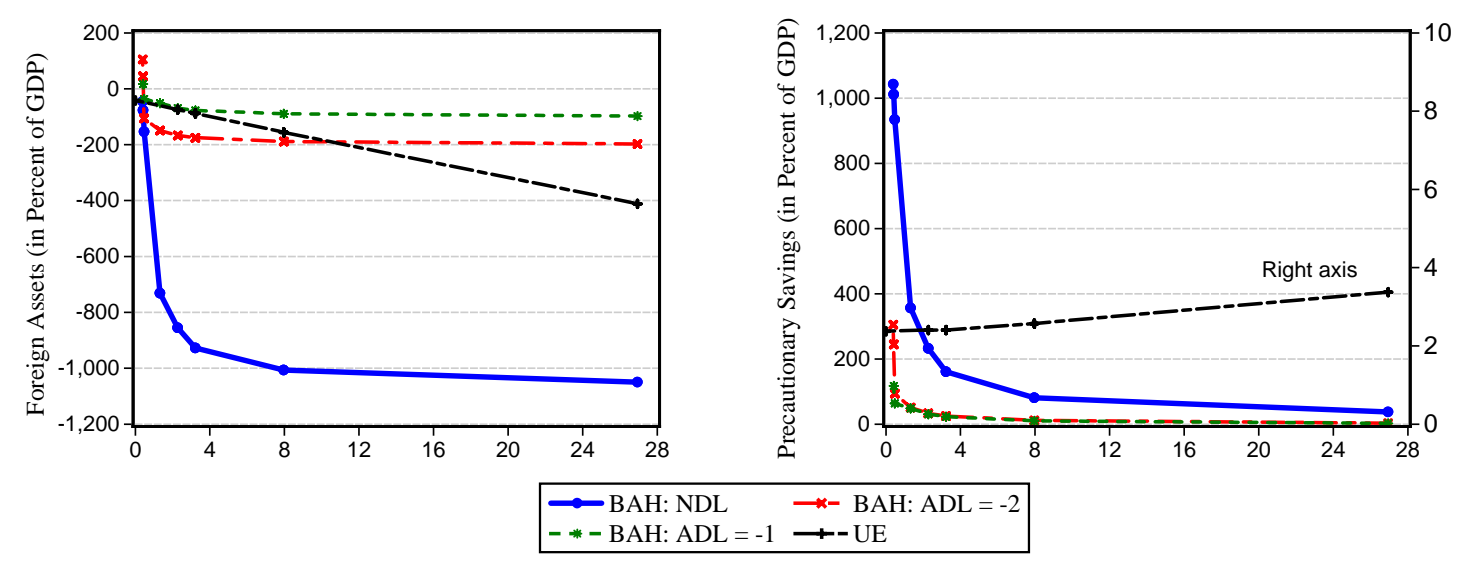


Figure 7. Financial Globalization: Lower Transaction Costs
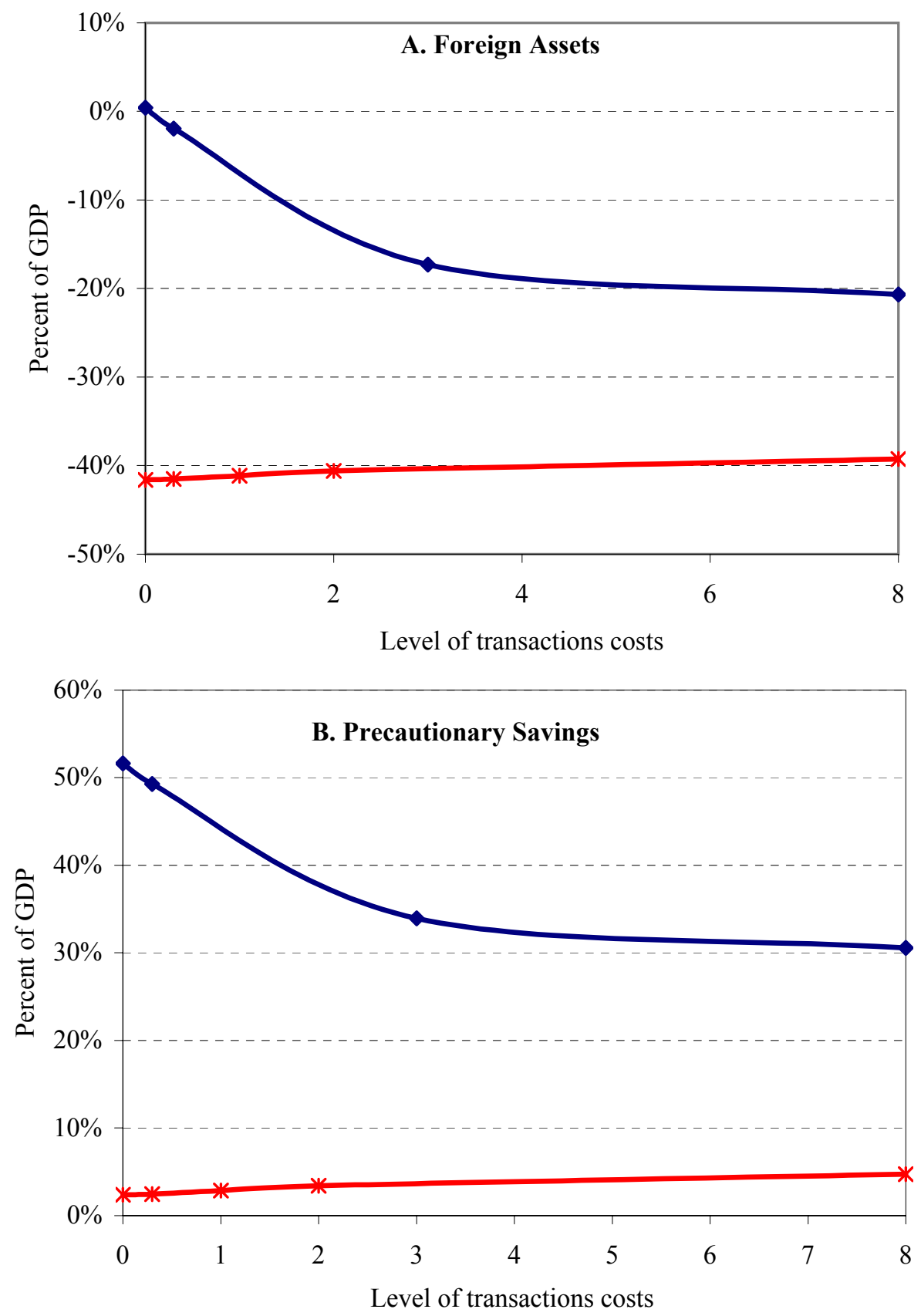

$\longrightarrow$ Bewley-Aiyagari-Hugget

*Uzawa-Epstein 


\section{Figure 8. One- and Two-Sector Models: Financial Globalization, Foreign Assets}

and Precautionary Savings.
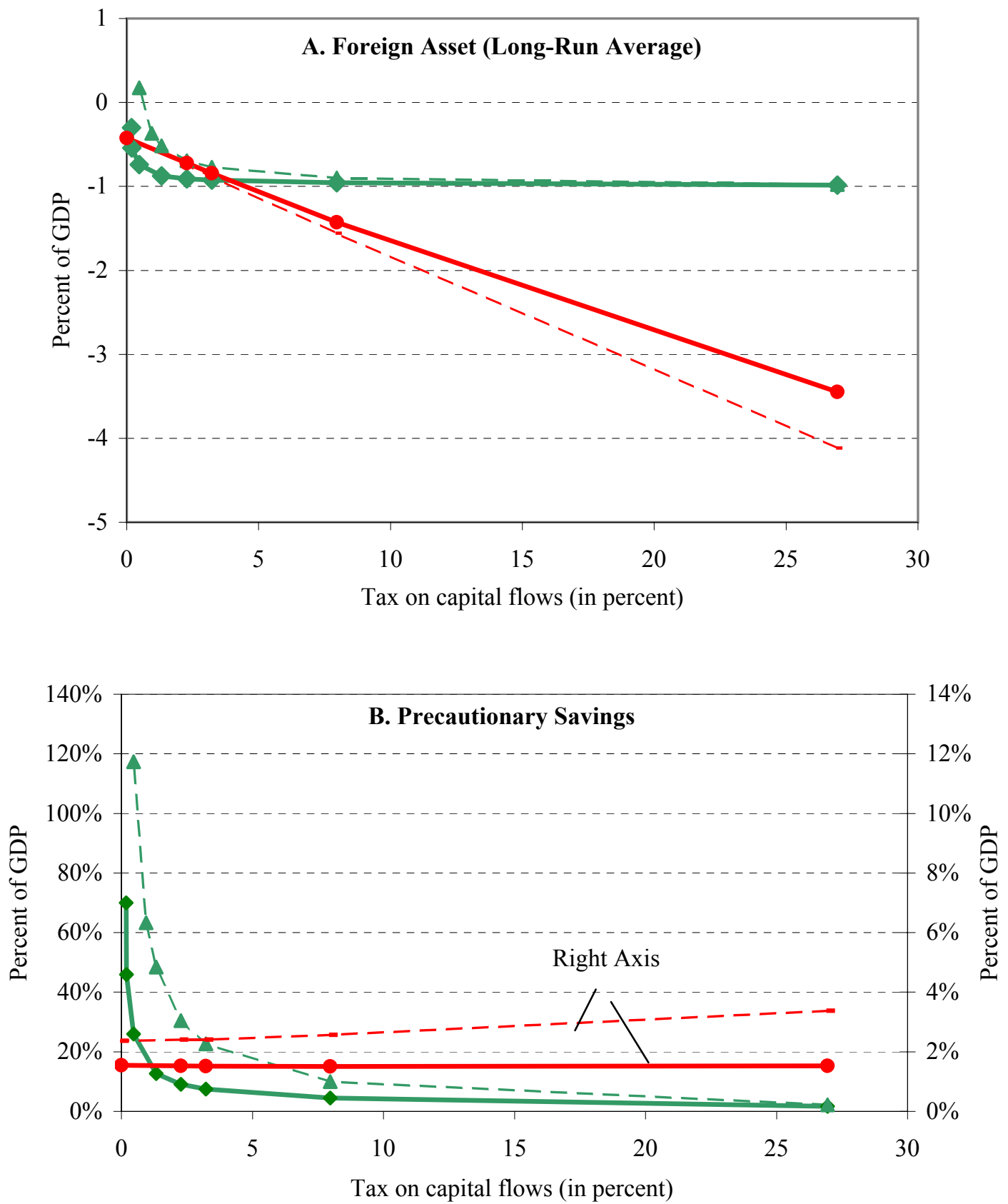

$\longrightarrow$ BAH two sectors:ADL $=-1.0-\triangle-$ BAH one sector:ADL $=-1$
UE two sectors
--- UE one sector


Figure 9. Sudden Stops under Alternative Preference Specifications (excess deviations from long-run average relative to frictionless economy)
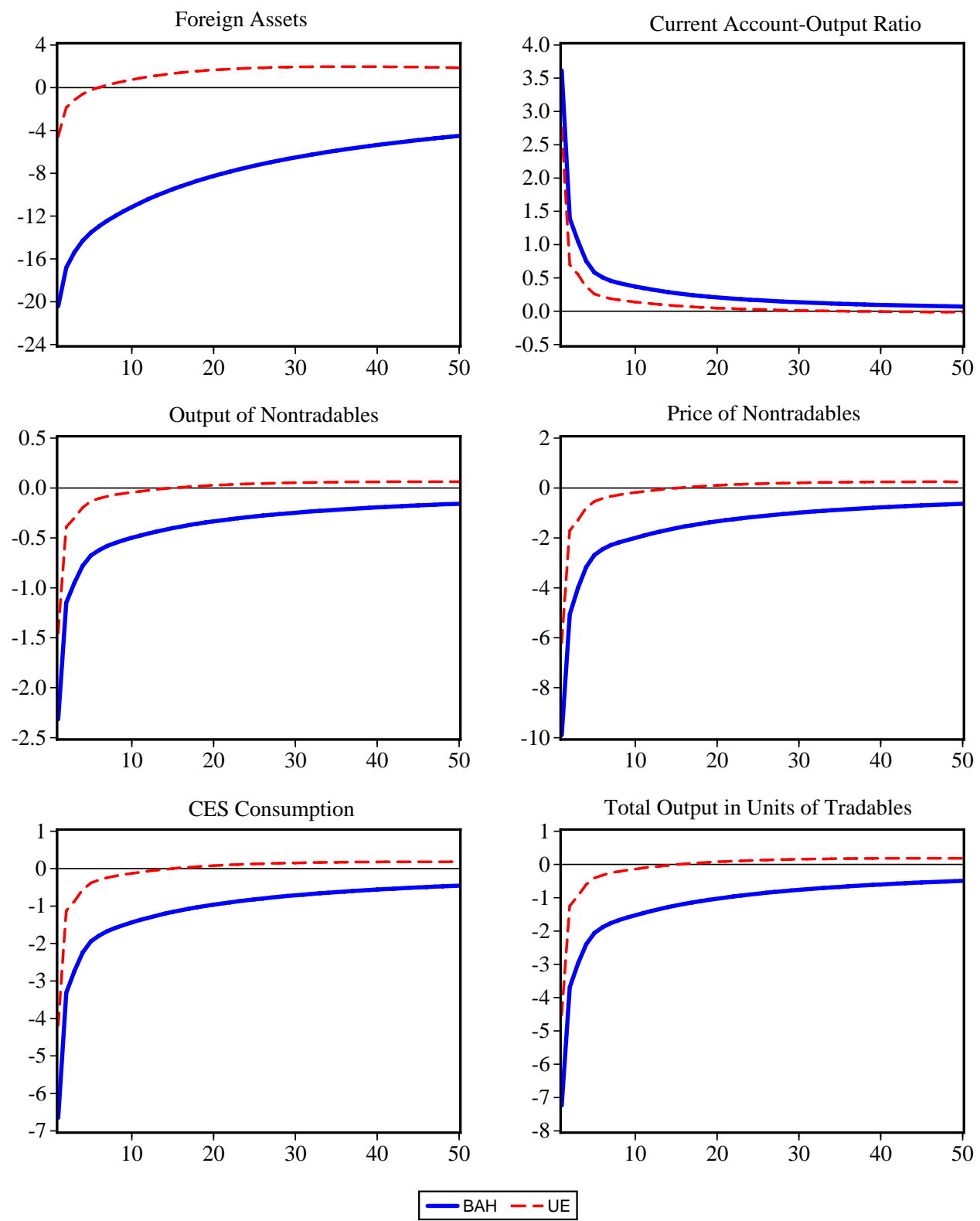

Note: The plots show forecast functions of equilibrium Markov processes in response to initial negative shocks to tradables output and TFP in nontradables, and an initial ratio of foreign assets to long-run GDP of -48.7 percent. The data are plotted as differences in percent deviations from long-run averages in the economies with credit constraints relative to those in the economies with perfect credit markets. Foreign assets are in percent of the long-run average of GDP. BAH refers to Bewley-Aiyagari-Hugget, and UE refers to Uzawa-Epstein 
Figure 10. Amplication Effects on Impact in the Sudden Stop Region

(Differences in deviations from mean with and without credit constrainst in response to one s.d. shocks)

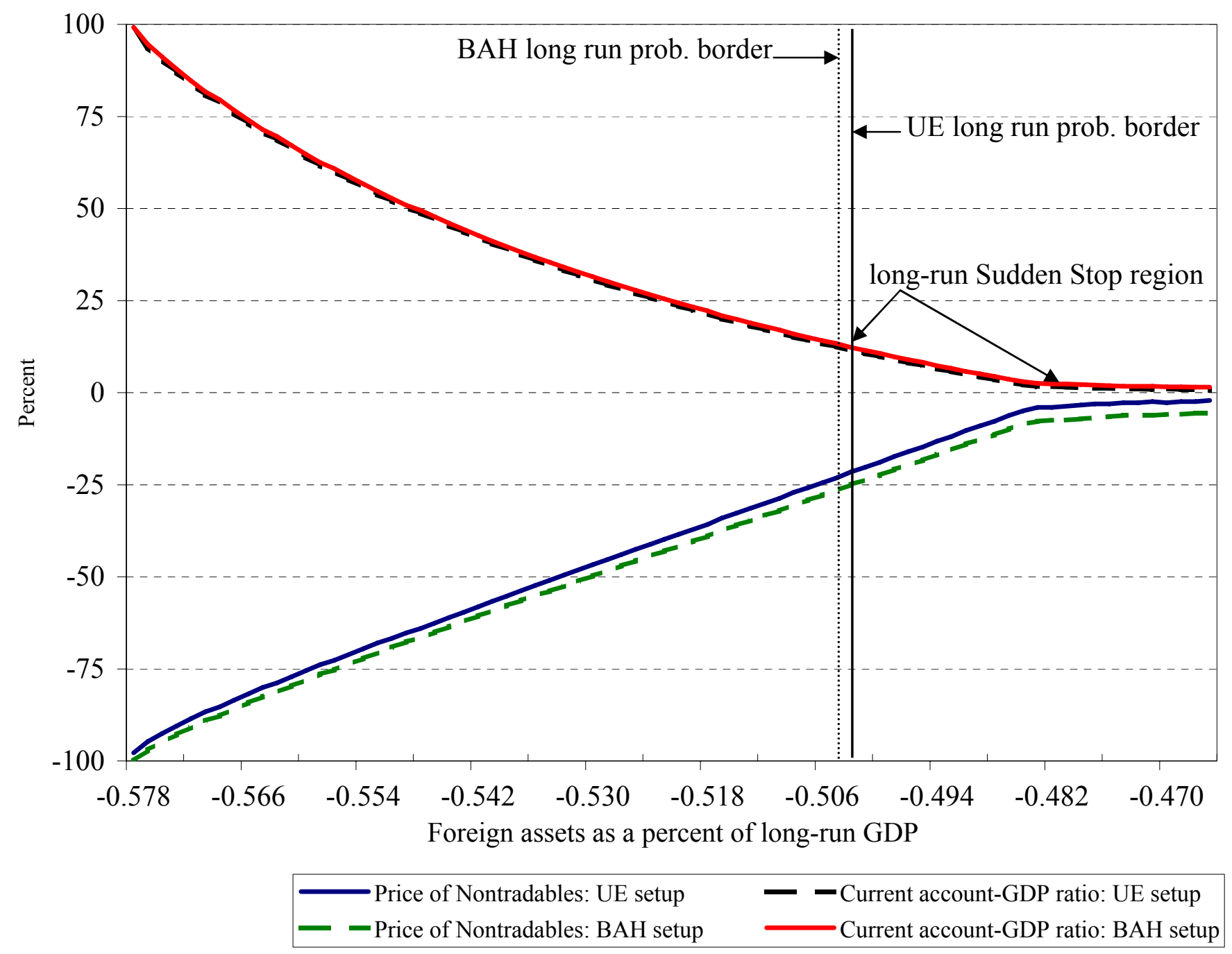

